Research Article

\title{
Layered Double Hydroxide Catalysts Preparation, Characterization and Applications for Process Development: An Environmentally Green Approach
}

\author{
Ateeq Rahman, Viswanadha Srirama Rajasekhar Pullabhotla ${ }^{2, *}$ \\ ${ }^{1}$ Department of Physics, Chemistry and Material Science, University of Namibia, Mandumedumefayo, \\ Post Bag13301, Windhoek, Namibia. \\ ${ }_{2}^{2}$ Department of Chemistry, University of Zululand, Private Bag X1001, KwaDlangezwa 3886, \\ South Africa.
}

Received: 29th August 2021; Revised: 25th November 2021; Accepted: $26^{\text {th }}$ November 2021 Available online: 23rd December 2021; Published regularly: March 2022

\section{Abstract}

The adage of new generation of fine chemicals process is the best process applied in the absence of conventional methods. However, many methods use different reaction parameters, such as basic and acidic catalysts, for example oxidation, reduction, bromination, water splitting, cyanohydrin, ethoxylation, syngas, aldol condensation, Michael addition, asymmetric ring opening of epoxides, epoxidation, Wittig and Heck reaction, asymmetric ester epoxidation of fatty acids, combustion of methane, $\mathrm{NO}_{\mathrm{x}}$ reduction, biodiesel synthesis, propylene oxide polymerization. Layered Double Hydroxides (LDHs) have received considerable attention due their potential applications in flame retardant and has excellent medicinal property for reducing acidity. These catalysts are characterized using analytical techniques, such as: X-ray diffraction (XRD), Fourier-transform infrared (FT-IR), Raman spectroscopy, Thermogravimetric-Differential Thermal Analyzer (TG-DTA), Scanning electron microscope (SEM), Transmission electron microscopes (TEM), Brunauer-Emmett-Teller (BET) surface area, $\mathrm{N}_{2}$ Adsorption-desorption, Temperature programmed reduction (TPR), X-ray photoelectrons spectroscopy (XPS), which gives its overall picture of its structure, porosity, morphology, thermal stability, reusability, and activity of catalysts. LDHs catalysts have proven to be economic and environmentally friendly. The above discussed applications make these catalysts unique from Green Chemistry point of view since they are reusable, and eco-friendly catalysts.

Copyright (C 2021 by Authors, Published by BCREC Group. This is an open access article under the CC BY-SA License (https://creativecommons.org/licenses/by-sa/4.0).

Keywords: Layered Double hydroxides; synthesis; applications; characterization; LDHs

How to Cite: A. Rahman, V.S.R. Pullabhotla (2022). Layered Double Hydroxide Catalysts Preparation, Characterization and Applications for Process Development: An Environmentally Green Approach. Bulletin of Chemical Reaction Engineering \& Catalysis, 17(1), 163-193 (doi: 10.9767/bcrec.17.1.12195.163-193)

Permalink/DOI: https://doi.org/10.9767/bcrec.17.1.12195.163-193

\section{Introduction}

Anionic clay materials are a class of $\mathrm{LDHs}$ and the general formula of $\mathrm{LDHs}$ is $\left[\mathrm{M}^{\mathrm{II}}{ }_{1-\mathrm{x}} \mathrm{M}^{\mathrm{III}} \mathrm{x}_{\mathrm{x}}(\mathrm{OH})_{2}\right]^{\mathrm{X}+}\left[\left(\mathrm{Am}^{-}\right)_{\mathrm{x} / \mathrm{m}} \cdot \mathrm{nH}_{2} \mathrm{O}\right] \mathrm{X}^{+}$, where $\mathrm{M}^{(\mathrm{II})}$ and $\mathrm{M}^{(\mathrm{III})}$ are the metal species being diand tri- valents and $\mathrm{A}$ is an anion (Figure 1) [1].

\footnotetext{
* Corresponding Author.

Email: PullabhotlaV@unizulu.ac.za (R.V.S.R. Pullabhotla); Telp.: +27-35-902 6155
}

LDHs are the host-guest materials consisting of positively charged metal oxide/hydroxide sheets with intercalated anions and water molecules [2]. There are enormous applications of $\mathrm{LDHs}$ catalysts, with few examples used as support for different catalytic materials [3-5] and as catalysts for organic transformations such as epoxidation reaction of olefins (styrene, cyclohexene) $\mathrm{Mg}-\mathrm{Al}$ hydrotalcite [6], Aldol and Knoevenagel condensation Ni-Al hydrotalcite [7], Heck- 
Suzuki reaction $\mathrm{Mg} \mathrm{Al}-\mathrm{LDH}-\mathrm{Pd}^{\circ}$ [8], hydroxylation of phenol, Michael reaction, transesterification CoNiAl hydrotalcite, $\mathrm{LDH}$ s as oxidation catalysts [9-11] and $\mathrm{CO}_{2}$ absorbents [9], anion exchangers Ni-Al-LDH-Sn [10]. LDHs has vast applications in the area of environmental catalysis (Table 1), CuMgAl LDHs, which can be used in diesel engine soot [11-13], ion exchange/adsorption [14], drugs-Levodopa LDH nano composite shows minimal toxicity potential of a PC12 cell Parkinson's disease model in a dose [15], anti-cancer nano medicine [16], Lysozyme-LDH for antimicrobial activity [17], $\mathrm{MgFe}$ LDH-Mo can be used for degradation of methyl orange by photochemical method [18], Iron(III) Porphyrin MgAl LDHs [19,20], electroactive and photoactive materials $\mathrm{MgAlCu} \mathrm{Hy}$ drotalcite [12], electrochemistry [21,22], fuel cell, and water splitting [22-26], LDHs carbon nano composites $\mathrm{Ni} / \mathrm{Co}$ supercapacitors [27], $\mathrm{Mg} \mathrm{Al} \mathrm{LDHs} \mathrm{nano} \mathrm{flakes} \mathrm{humic} \mathrm{acid} \mathrm{adsorption}$ [28], Biochar-Fe LDH for phenol removal [29], waste water treatment [30], LDHs nano carriers for drug delivery [31], LDHs based nano systems for cancer therapy [32], $\mathrm{NiCo}_{2} \mathrm{~S}_{4} @ \mathrm{NiFe}$ $\mathrm{LDH}$ hollow spheres as electrocatalysts [33]. Many reviews have been published focusing over particular examples, i.e. LDHs [34], LDHs hybrids [35], nanocarbons [36], Graphene LDHs nanocamposites [37], biomaterials-LDHs [38], LDHs preparation by continuous flow process [39], LDHS [40], LDHs present and future [41], synthesis characterization and applications [42], synthesis of new hydrotalcite type catalysts [43], intercalation method of organic molecules into LDHs [44], microwave-assisted synthesis on the physico-chemical properties of pamoate-intercalated layered double hydroxide [45], microwave hydrothermal treatments on the crystallinity properties of hydrotalcite-like compounds [46], microwave effect during aging on the porosity and basic properties of hydrotalcites [47], effect of synthesis conditions on the formation of layered double hydroxides [48], hierarchical nanocomposites derived from nanocarbons and layered double hydroxides, carbon nanoforms [49], metal nanoparticles [50,51], organic guests [52,53], and oxometallates $[54,55]$ used for the preparation of interesting LDH-based hybrids, corrosion protection [56], anti corrosion [57], metallurgical application [58], $\mathrm{Mg} \mathrm{Al}$ coatings on alloy [59], $\mathrm{NiFeAl}$ LDHs from electroplating sludge [60].

The concept of green chemistry is quite notable hence the authors presents the difference between conventional and green chemistry of heterogeneous catalysts in this section. The two key factors from Green chemistry point of view are (a) E-factor and (b) Atom economy. (a) $\mathrm{E}$ factor is defined as the mass ratio of waste to desired product formed. The $\mathrm{E}$ factor is the actual amount of waste produced in the process, defined as everything but the desired product. It takes the chemical yield into account which includes reagents, solvents losses, all process aids and, in principle, even fuel (although it is often difficult to quantify). A higher $\mathrm{E}$ factor means more waste generated and creating, greater negative environmental impact. The ideal $\mathrm{E}$ factor is zero. A very simple calculated outcome is quite simply, it is kilograms (of raw materials) in, minus kilograms of desired product formed, divided by kilograms of product out. (b) Atom economy is calculated by dividing the molecular weight of the desired product by the sum of the molecular weights of all substances produced in the stoichiometric equation. It is calculated by dividing the molecular

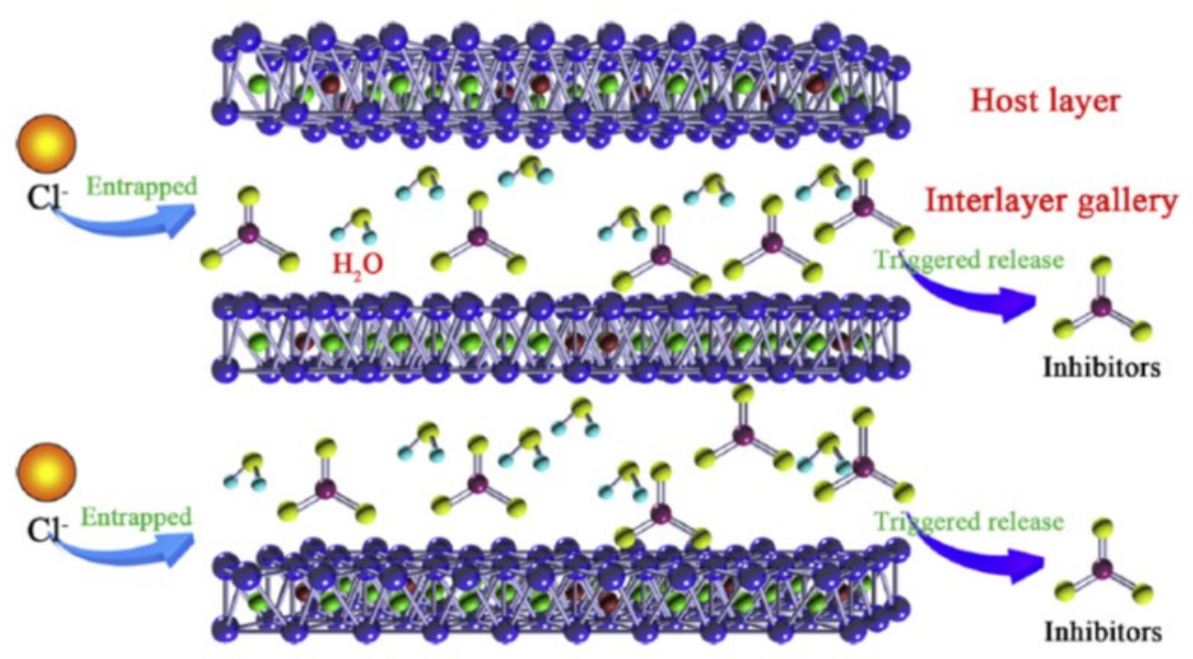

Figure 1. Schematic representation of the entrapment of the aggressive chloride ions and the triggered release of anionic corrosion inhibitors from $\mathrm{LDHs}_{\mathrm{s}}$ [28]. 
Table 1. Applications of LDHs.

\begin{tabular}{|c|c|c|}
\hline No. & Applications & Reference \\
\hline 1 & $\mathrm{Mg} \mathrm{Al} \mathrm{Hydrotalcite} \mathrm{Epoxidation} \mathrm{of} \mathrm{olefins.}$ & [6] \\
\hline 2 & Aldol and Knoevenagel condensation Ni-Al hydrotalcite. & [7] \\
\hline 3 & Heck-Suzuki reaction $\mathrm{Mg}$ Al-LDH-Pdo. & {$[8]$} \\
\hline 4 & $\begin{array}{l}\text { Hydroxylation of phenol, Michael reaction, transesterification CoNiAl hy- } \\
\text { drotalcite, LDHs as oxidation catalysts. }\end{array}$ & {$[9-11]$} \\
\hline 5 & $\mathrm{CO}_{2}$ absorbents & [9] \\
\hline 6 & Anion exchangers Ni-Al-LDH-Sn & {$[10]$} \\
\hline 7 & Environmental catalysis Diesel Engine Soot. & [11-13] \\
\hline 8 & Ion-exchange adsorption & {$[14]$} \\
\hline 9 & Drugs-Levodopa LDH nano composite & [15] \\
\hline 10 & Anticancer nano medicine & [16] \\
\hline 11 & Lysozyme-LDHs for antimicrobial activity & [17] \\
\hline 12 & Degradation of methyl orange with LDHs by photochemical reaction & {$[18]$} \\
\hline 13 & Iron(III) Porphyrin MgAl LDHs. & {$[19,20]$} \\
\hline 14 & Electroactive and photoactive materials $\mathrm{MgAlCu}$ Hydrotalcite & {$[12]$} \\
\hline 15 & LDHs carbon nano composites Ni/Co supercapacitors. & [27] \\
\hline 16 & Electrochemistry-Fuel cell and Water splitting. & [27] \\
\hline 17 & $\mathrm{Mg} \mathrm{Al} \mathrm{LDHs} \mathrm{nano} \mathrm{flakes} \mathrm{humic} \mathrm{acid} \mathrm{adsorption}$ & [28] \\
\hline 18 & Biochar-Fe LDH for phenol removal & [29] \\
\hline 19 & Waste water treatment & [30] \\
\hline 20 & LDHs nano carriers for drug delivery & [31] \\
\hline 21 & LDHs hybrids & [35] \\
\hline 22 & Nanocarbons, & [36] \\
\hline 23 & Graphene LDHs nanocomposites & [37] \\
\hline 24 & Biomaterials-LDHs & [38] \\
\hline 25 & LDHs preparation by continuous flow process, & [39] \\
\hline 26 & LDHs present and future & [39-40] \\
\hline 27 & $\begin{array}{l}\text { Synthesis characterization and applications and Synthesis of new hy- } \\
\text { drotalcite type catalysts, }\end{array}$ & {$[42,43]$} \\
\hline 28 & Intercalation method of organic molecules into LDHs. & {$[44]$} \\
\hline 29 & Microwave assisted synthesis of LDHs & [45-49] \\
\hline 30 & $\begin{array}{l}\text { Hierarchical nanocomposites derived from nanocarbons and layered double } \\
\text { hydroxides, carbon nanoforms }\end{array}$ & {$[50]$} \\
\hline 31 & Metal nanoparticles & {$[50,51]$} \\
\hline 32 & Organic Guests & {$[52,53]$} \\
\hline 33 & Oxometallates & {$[54,55]$} \\
\hline 34 & Corrosion protection & {$[56]$} \\
\hline 35 & Anti-corrosion & [57] \\
\hline 36 & Metallurgical application & [58] \\
\hline 37 & $\mathrm{Mg} \mathrm{Al}$ coatings on alloy & [59] \\
\hline 38 & $\mathrm{Ni} \mathrm{Fe} \mathrm{Al} \mathrm{LDH}$ s from electroplating sludge & {$[60]$} \\
\hline 39 & Calcined hydrotalcites have been used for aldol & [61] \\
\hline 40 & Knoevenagel and Claisen-Schmidt condensations. & [62] \\
\hline 41 & $\begin{array}{l}\text { Calcined hydrotalcites have been used for aldol, Knoevenagel and Claisen- } \\
\text { Schmidt }\end{array}$ & [62] \\
\hline 42 & $\mathrm{Fe}_{3} \mathrm{O}_{4} / \mathrm{ZnCr} \mathrm{LDH}$ s nanohybrids Photo catalysts & [63] \\
\hline 43 & $\mathrm{SnO}_{2} \mathrm{Zr}_{2} \mathrm{O}_{4}$ Photo catalysts & [64] \\
\hline 44 & MgZn LDHs Photo catalysts & [65] \\
\hline
\end{tabular}


weight of the product by the sum total of the molecular weights of all substances formed in the stoichiometric equation for the reaction involved. The conventional processes produce copious amounts of inorganic salts can similarly be largely replaced with stoichiometric mineral acids, such as $\mathrm{H}_{2} \mathrm{SO}_{4}$, and Lewis acids and stoichiometric bases, such as $\mathrm{NaOH}, \mathrm{KOH}$, and $\mathrm{NaOMe}$ with recyclable solid bases, in a variety of organic transformations it is a focus of recent attention [66] preferably in catalytic amounts. However, the technology has not changed for a century replacing the traditional processes with the heterogeneous catalysts, such as synthetic hydrotalcite clays which are also known as layered double hydroxides (LDHs) are examples. Calcined hydrotalcites have been used for aldol [61], Knoevenagel [62], and ClaisenSchmidt [62] condensations to name few (Table 1). Hence due to the toxic waste produced heterogeneous catalysts can minimize toxic waste with concept of green chemistry.

The LDHs has Green chemistry concept that promotes environmental and development of sustainable technologies. LDHs is one of the key technologies on which new approaches to green chemistry are based. Green catalysis recently made significant progress in several areas such as the design of safer chemicals and environmentally benign solvents, and the development of renewable feedstocks, such as biomass. In a nut shell, it is necessary to design $\mathrm{LDHs}$ catalysts and catalytic processes with in order to follow the environmental regulations.

\section{Crystal Structure of Hydrotalcite}

$\mathrm{LDHs}$ structural role remains to reconstruct the lamellae to establish the electro-neutrality throughout the linkage; where water molecules are distributed. LDHs structures are usually derived from mineral brucite, $\mathrm{Mg}(\mathrm{OH})_{2} . \mathrm{Mg}$ ions are present in $\mathrm{Mg}(\mathrm{OH})_{2}$. In octahedral sites $\mathrm{Mg}$ ions are situated with six $\mathrm{OH}-$ groups pointing at the vertices, whereas they are pointing the $\mathrm{H}$ atoms in the path of the interlayer spacing. Hence, the octahedral sites are interconnected together by boundaries creating the planar and neutral extended layers interconnected with $\mathrm{H}$ bonds. The crystal structure can have rhombohedral of hexagonal symmetry. The bivalent cations are moderately exchanged with trivalent ones, and the positively charged sheets are formed. In brucite layers the electrostatic interactions takes place with hydrogen bonds, this controls the resulting arrangement of the layers. The crystal structure arising from the stacking of sheets could be rhombohedra or hexagonal symmetry. Howev- er, maximum number of synthetic LDHs exhibits rhombohedral R-3 unit cell. A very important criterion for the LDHs stability exhibits due to the cations situated in the octahedral sites and must possess similar ionic radii. However, the ratio of $\mathrm{M}^{2+} / \mathrm{M}^{3+}$ is between 1-3. Hence, in principle, there are no restrictions for the anionic species that balances the positive residual charges [65].

\section{Methods for Preparation of LDHs}

The most common methods for the synthesis of LDHs are discussed below.

\subsection{Mechanochemical Method}

This method has been effectively used for the intercalation purposes. A simple method is used by grinding with mortar and pestle and it is similar to anion exchange method. The prepared $\mathrm{NO}_{3}{ }^{-}$ion containing $\mathrm{LDHs}$ was used as a precursor material and anion is added with a very minute amount of $\mathrm{NaOH}$ and grounded manually. During grinding process, the $\mathrm{NO}_{3}{ }^{-}$ ions with desired molecules are in anionic form [67].

\subsection{Liquid Assisted Grinding Method}

The $\mathrm{MgAl}-\mathrm{NO}_{3}$ with the formula

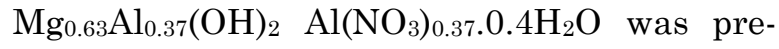
pared using the urea method [67] which resulted in the formation of $\mathrm{Mg} \mathrm{Al}$ carbonate hydrotalcite. Instantaneously, it was converted into its nitrate form by titration. It was then dispersed in a $\mathrm{NaNO}_{3}$ solution $(\mathrm{mol} / \mathrm{L})$ and titrated by a $\mathrm{HNO}_{3}$ solution $(0.1 \mathrm{~mol} / \mathrm{L})$ by means of an automatic titrator (I tralab VIT 90 Video Titrator Radiometer, Copenhagen) operated at $\mathrm{pH}$ Stat mode at $\mathrm{pH} 5$.

\subsection{LDHs Synthesis using Microwave}

The ageing process takes place in microwave conditions, however the irradiation of the microwave is taken into consideration where very fast ageing process takes place, for about 15-60 $\mathrm{min}$ [68]. The co-precipitation and urea techniques can be utilized as a part of a synthesis using microwave [69] rather than a reflux aging process. Homogeneous sized particles are synthesized using microwave aging process, that are in smaller size than nano particles produced using reflux method [69]. The main advantage of shorter duration of aging process is to prevent the formation of impurities. However, with long duration of time for the aging process changes the formation of impurities which are quite high. Choudhary et al. 
$[70,71]$ reported that the $\mathrm{Ni} \mathrm{Al}$ hydrotalcite is effective for oxidation and reduction reactions as $\mathrm{NiO}$ in association with oxide of aluminium from TPR studies. Kantam et al. [72] reported that the $\mathrm{MgAlCO}_{3}$ hydrotalcite hence the carbonate is favouring ring opening of epoxides.

\subsection{Co-precipitation Method}

This is a commonly and economic method used to prepare LDHs since it is usually prepared in a solitary step with a good yield [72]. The $\mathrm{M}^{2+}$ and $\mathrm{M}^{3+}$ solutions of cations are stirred together with another solution of anion to be intercalated, under constant stirring at room temperature. Hence, the $\mathrm{pH}$ of the mixture is maintained at 9 by addition of basic solution of sodium hydroxide and sodium carbonate of known concentration to favour the precipitation of cation hydroxides. To support the intercalation of the preferred anions, the ideal ions of cation salts are nitrates or chlorides that has low affinity on the brucite layers. Hence, the absence of $\mathrm{CO}_{2}$ in water is crucial for the preparation of intercalated LDHs. A vital measure is to be adopted with the use of de-ionized water in an inert atmosphere, this is to avoid the interaction of the solution with air/moisture. The impurity phase formation is determined with the perfect choice of $\mathrm{pH}$ value, and depends on the cations ratio. The crystallinity of the resulting LDHs nano hybrids slowly increases for six hours at $80{ }^{\circ} \mathrm{C}$. From literature it is evident that, there are many examples of this methods that are reported for the synthesis of nanocomposites which are used for drug delivery, intercalation of drugs, anticancer agents [73], pesticides [74], amino acids [75], peptides, and antibiotics [76].

\subsection{Hydrothermal Synthesis Method}

The hydrothermal synthesis usually begins with fast mixing of oxides/hydroxides of $\mathrm{M}^{2+}$ and $\mathrm{M}^{3+}$ cations. The solution of desired acid or salt is introduced into the suspension, then the obtained dispersed solution is stirred at high temperature in 3-neck round bottom flask or in hydrothermal reactor. The advantages of this method is to minimize the formation of undesirable waste, which causes pollution to the environment. Additionally, since only metal hydroxides, shows very short affinity towards $\mathrm{LDH}$ interlayers that are existing. However, the hydrothermal method is very effective in intercalating the organic guest species between the LDH interlayers. This method is very important to control and achieve the desired particle size and morphology which usually de- pends on parameters set. In many developmental processes, this method is utilized to improve the crystalline structure of LDHs for exhibiting excellent properties [76].

\subsection{Synthesis of LDHs by Sol-gel Method}

LDHs are prepared by Sol-gel process, the mechanism shows the formation of sol during hydrolysis and the partial condensation of a metallic solution which is the first step, and the second step is followed by gel formation. Hence, metallic alkoxides, acetates, or acetyl acetonates, and inorganic salts are used as metallic precursors. The interesting properties of the resulting solid LDHs depends on certain defined parameters, such as hydrolysis and slow condensation of metallic precursors, that are finely tuned by regulating different reaction parameters adopted such as $\mathrm{pH}$, concentration of the metallic precursors, solvent and temperature. The materials synthesized by Solgel method shows pore sizes that are well controlled and has high specific surface area as reported by Yang et al. [77].

\subsection{Reconstruction Method}

This is the most important and interesting method which has advantages of the 'memory effect' of LDHs. In detail, these materials, once heated at elevated temperatures of about 650 ${ }^{\circ} \mathrm{C}$ in inert conditions, results in the formation of mixture of metal oxides that are easy to regenerate the hydroxide layers when exposed to water. These are highly applicable in base catalysed reactions such as Aldol, Michael, and Wittig reactions [78]. The prepared LDH-CO3 are thermally decomposed to a mixture of oxides which is easily dispersed in the desired anion solution under inert conditions in deionised water in order to avoid the $\mathrm{CO}_{3}{ }^{2-}$ contamination. This is the common method used when larger anions have to be intercalated in LDHs. Hence, this method is the choice of method for intercalation, with different anions, such as $\mathrm{Cl}^{-}$or $\mathrm{NO}_{3}{ }^{-}$[78]. The incorporation of competing anions is also restricted, depending on parameters such as $\mathrm{pH}$ value which increases leading to favour the $\mathrm{OH}^{-}$formation. Various examples have been reported in literature, such as pesticides, vitamins and antibiotics [79].

\subsection{Ionic Exchange Method}

Ion exchange and co-precipitation are complementary methods. In precise, the selected metal ions which are at high $\mathrm{pH}$ and/or when there is a robust prospect of interaction 
amongst guest species and metal ions, they are typically seen as unstable [79]. With the anionexchange process, the LDHs structure usually contains $\mathrm{Cl}^{-}$or $\mathrm{NO}_{3}{ }^{-}$as interlayer anions, that are added to the concentrated solution of the anions. The resulting solution is stirred overnight at temperature range of $50-70{ }^{\circ} \mathrm{C}$. The exchange efficiency differs usually depends on the capability of the exchanged anions to stabilize the layered structure. However, the two steps discussed above are very important, but many examples are cited in literature in drugs [79], and pesticides [79] intercalations.

\subsection{LDH Synthesized in T-Mixer with Ultra- sonic Process}

A mixture of $0.03 \mathrm{~mol} \mathrm{L1} \mathrm{Mg}\left(\mathrm{NO}_{3}\right)_{2}$ and 0.01 mol L1 $\mathrm{Al}\left(\mathrm{NO}_{3}\right)_{3}$ and solution $\mathrm{NH}_{3} \mathrm{H}_{2} \mathrm{O}$ (100 $\mathrm{mL}$ ) with certain concentration was simultaneously transported into a 'T-type' impingingstream reactor by means of metering pumps at the rate of $100 \mathrm{rpm}$ to produce $\mathrm{MgAl} \mathrm{LDHs}$. Ultrasonic processing was also applied during this process and the frequency was kept at 20 $\mathrm{kHz}$. The $\mathrm{pH}$ of the whole solution was continuously kept at 10 through regulating the concentration of $\mathrm{NH}_{3} \mathrm{H}_{2} \mathrm{O}$. The resulting mixture was washed with water several times until it recached $\mathrm{pH}=7$ and then it was dried at $100{ }^{\circ} \mathrm{C}$ in an oven. The resulting material was denoted as "T-mixer", TU-LDHs [80].

\subsection{LDH Synthesized by Hybrid Two-step Method}

MgAl layered double hydroxides were prepared using a hybrid two-step preparation approach. The hybrid two-step preparation comprises of the mother solution prepared in 'Tmixer' accompanying with ultrasonic processing (first step) and the following step of coprecipitation (second step) process. The mother solution was synthesized according to the preparation method of the Section 3.9. About $50 \mathrm{~mL}$ of the mother solution from Section 3.9 which was added into a beaker for continuous stirring. Then, $150 \mathrm{~mL}$ of salt solution with a fixed concentration of $0.03 \mathrm{~mol} / \mathrm{L} \mathrm{Mg}\left(\mathrm{NO}_{3}\right)_{2}, \quad 0.01$ $\mathrm{mol} / \mathrm{L} \mathrm{Al}\left(\mathrm{NO}_{3}\right)_{3}$ and $1 \mathrm{~mol} / \mathrm{L}$ of $\mathrm{NH}_{3} \mathrm{H}_{2} \mathrm{O}$ were simultaneously added to the mixture at the second step. The addition rate of salt solution was controlled by regulating the speed of peristaltic pump, where the $\mathrm{pH}$ of the whole solution was continuously kept at 10 . The final obtained materials were filtered and then washed with distilled water until $\mathrm{pH}=7$ was reached, then followed by drying at $100{ }^{\circ} \mathrm{C}$ in an oven. The ob- tained material was denoted as "T-Mixer "TUC-LDHs [80].

\section{Characterization of LDHs Catalysts}

$\mathrm{LDHs}$ are usually characterized by X-ray diffraction (XRD), Differential Scanning Calorimetry-Temperature Gravimetric Analysis (DSC-TGA), Fourier Transform Infra Red (FTIR), X-ray Photoelectron Spectroscopy (XPS), Raman, Temperature Programmed Reduction (TPR), and Scanning Electron Microscopy (SEM) spectroscopy.

\subsection{SEM Characterization of CoAl LDHs}

SEM analysis is a powerful investigative tool which used to characterize which produces high magnification images of a sample's surface. Basically in LDHs samples they are highly crystalline. Intersected, nearly hexagonalshaped particles, interconnected with each other, enough uniform as sizes (average size equal to $100 \mathrm{~nm}$ ) are formed in the case of the hydrotalcite-like clay $\mathrm{Mg} \mathrm{Al} \mathrm{LDH}$. Bayu [81] reported that $\mathrm{Mg} \mathrm{Al}$ (2:1 and 3:1) prepared by coprecipitation method showed morphology of thin crystals of nanoparticles of agglomerates of $\mathrm{Mg}$ - $\mathrm{Al}$ hydrotalcites [81]. Wu et al. [82] reported the characteristic SEM morphologies of $\mathrm{LDHs}$ samples. The morphology of Co-Al LDHs synthesized at $80{ }^{\circ} \mathrm{C}$ is different from that of synthesized at $140{ }^{\circ} \mathrm{C}$, and the crystallization temperature on the morphology of LDHs. The $\mathrm{LDHs}$ at low crystallinity were assembled to observe as a single layer. Wu et al. [82] reported that the morphologies of LDHs were further confirmed with TEM as micro morphologies, and the LDHs were formed as hexagonal layered structures. In addition, the agglomeration of particles was observed in LDHs samples that resulted due to the physical entanglement of organic anions. Zhai et al. [83] reported the agglomerated layers of Co-Al LDHs samples through SEM analysis, the samples were prepared at $80^{\circ} \mathrm{C}$. These SEM results revealed the morphology of Co-Al LDHs which shows interesting properties such as high chemical and thermal stability, intercalated anions with interlayer spaces, ease of synthesis, unique structure, uniform distribution of different metal cations in the brucite layer, surface hydroxyl groups, flexible tenability, Oxo bridged linkage, swelling properties and ability to intercalate different type of anions, such as oxalate, $t$-K-But oxide, LDA-Lithium di-isopropyl amide [84]. 


\subsection{XPS Characterization of LDHs:}

$\mathrm{X}$-ray photoelectron spectroscopy (XPS) is very important tool to detect the chemical composition and evaluate the chemical bonding states (or oxidation state) as well as the electronic structure of the surface. Nishesh [85] reported the chemical composition determined by the full XPS spectrum of $\mathrm{Zn}-\mathrm{Fe} \mathrm{LDH}$ which showed the presence of $\mathrm{C}, \mathrm{O}, \mathrm{N}, \mathrm{Fe}$, and $\mathrm{Zn}$. The presence of carbon is due to carbonated anions in the LDH material. The high-resolution XPS (HRXPS) spectrum of $O$ 1s deconvoluted into three peaks where binding energy at $528.41 \mathrm{eV}$ and $530.07 \mathrm{eV}$ were ascribed due to the lattice oxygen $\left(\mathrm{O}_{2}{ }^{2-}\right)$ and surface hydroxyl groups of metal centers, respectively. The broad peak at $530.94 \mathrm{eV}$ corresponds to the physisorbed/chemisorbed water molecules, carbonate, and nitrate ions [85]. The $\mathrm{Fe}$ 2p3/2 peak at $710.74 \mathrm{eV}$ and $\mathrm{Fe} 2 \mathrm{p} 1 / 2$ peak at 724.16 $\mathrm{eV}$ along with satellite peaks at $717.82 \mathrm{eV}$ $(2 \mathrm{p} 3 / 2)$ and $733.04(2 \mathrm{p} 1 / 2)$ related to the existence of $\mathrm{Fe}^{3+}$ oxidation state [85]. Two noticeable spin-orbit peaks observed at $1020.30 \mathrm{eV}$ and $1043.53 \mathrm{eV}$ were due to $\mathrm{Zn}^{2+}$ [85]. Fe and $\mathrm{Zn}$ were distributed homogeneously in the material. Where the surface $\mathrm{Zn} / \mathrm{Fe}$ ratio was 1.9 . The XPS results together with the $\mathrm{LDHs}$ was reported by Karolina [86]. However, in order to characterize the nature of interlayer anion and structural changes in the reference samples along with increasing molar ratio, the XPS analysis of $\mathrm{C} 1 \mathrm{~s}$ and $\mathrm{Mg} 1 \mathrm{~s}$ was performed for the reference samples, as well as their analogues derived from minerals. The XPS analysis penetration depth was approximately $9 \mathrm{~nm}$. The C1s peaks exhibited two maxima which is ascribed due to the organic carbon contamination $(\sim 285 \mathrm{eV})$ and carbonates $(\sim 290 \mathrm{eV})$. The $\mathrm{C}$ content in all samples was equal to $\sim 2.0 \% \mathrm{wt}$. which is consistent with the results of elemental analysis. Peaks fitting revealed components assigned to: $\mathrm{CC}(284.8 \mathrm{eV}) ; \mathrm{C}-\mathrm{O}-\mathrm{C}(286$ $\mathrm{eV}) ; \mathrm{C}=\mathrm{O}(286.6 \mathrm{eV}) ; \mathrm{O}-\mathrm{C}=\mathrm{O}(287.5 \mathrm{eV}) ; \mathrm{CO}_{3^{2-}}$ $(289 \mathrm{eV})$ and $\mathrm{HCO}_{3}{ }^{-}(290 \mathrm{eV})[86]$.

\subsection{FT-IR Characterization of CoAl LDHs}

FTIR Spectroscopy, is a vital analytical technique used to identify organic, polymeric, and, in some cases, inorganic materials ans study its functional group's. The FTIR spectra of the LDHs reveals bands that are characteristics of hydrotalcite-like compounds. The broad and strong band centred at $3400 \mathrm{~cm}^{-1}$ is ascribed due to the stretching of the $\mathrm{OH}$ bond of the hydroxyl groups and interlayer of $\mathrm{H}_{2} \mathrm{O}$ molecules in LDHs samples [87]. The shoulder around $3050 \mathrm{~cm}^{-1}$ is ascribed due to the $\mathrm{H}_{2} \mathrm{O}-\mathrm{CO}_{3}{ }^{2-}$ interlayer bridging mode by hydrogen bonds [87]. The weak band at $1630 \mathrm{~cm}^{-1}$ is attributed due to the $\mathrm{H}_{2} \mathrm{O}$ bending deformation located in interlayer spacing on the LDHs. The sharp, intense vibration bands observed around $1370-1380 \mathrm{~cm}^{-1}$ were designated to the asymmetric stretching of $\mathrm{CO}_{3}{ }^{2-}$ anions. This band is broad, which is ascribed due to the presence of nitrate ions from the starting salts, principally due to the mode of vibration of $\mathrm{NO}_{3}{ }^{-}$is generally overlapped by the mode of vibration of $\mathrm{CO}_{3}{ }^{2-}$ [87]. The bands are recognized at 460,550 , and $790 \mathrm{~cm}^{-1}$ are credited to the $\mathrm{Al}-\mathrm{O}$ condensed groups, the $\mathrm{Zn} / \mathrm{Al}-\mathrm{OH}$ translation and the $\mathrm{Al}-\mathrm{OH}$ deformation, correspondingly. For example the $\mathrm{Zn}-\mathrm{Al}-\mathrm{CO}_{3}$ sample, the band around $1365 \mathrm{~cm}^{-1}$ is due to the antisymmetric stretching mode of carbonate, and bands observed around 870 and $680 \mathrm{~cm}^{-1}$ are ascribed due to the weak non-planar bending mode and the angular bending mode of carbonate present in the interlayer of LDH. The FTIR spectra of $\mathrm{Zn}-\mathrm{Al}-\mathrm{NO}_{3}$ reveals a strong peak around $1380 \mathrm{~cm}^{-1}$ and is endorsed due to the antisymmetric stretching mode of the nitrate anion present in the LDHs [87]. The bands recorded around 839 and $670 \mathrm{~cm}^{-1}$ are ascribed due to the weak out-of-plane symmetric deformation mode and the anti-symmetric deformation mode of nitrate, correspondingly [87].

\subsection{Raman Spectra Characterization of LDHs}

Raman spectroscopy is a spectroscopic method used to detect vibrational, rotational, and other states in a molecular system, capable of probing the chemical composition of materials. Luiz [88] reported that the Raman spectra shows bands in the region of $470 \mathrm{~cm}^{-1}$ which is ascribed due to the vibration connections of $\mathrm{Al}-\mathrm{O}-\mathrm{Al}$ present in the layers of $\mathrm{Mg}-\mathrm{Al}-\mathrm{LDHs}$ sample. Nishesh [85] reported the Raman spectra of pristine, $\mathrm{P}$-adsorbed $(\mathrm{pH}$ 8), P-adsorbed ( $\mathrm{pH}$ 5), and P-desorbed $\mathrm{Zn}-\mathrm{Fe} \mathrm{LDH}$. The Raman analysis of phosphate adsorbed $\mathrm{Zn}-\mathrm{Fe}$ $\mathrm{LDH}$ at $\mathrm{pH} 5$ and at $\mathrm{pH} 8$ revealed significant fluctuations in the peak position and intensity a compared with the pristine LDH [88]. At $\mathrm{pH}$ 5 , signal intensities for $\mathrm{M}-\mathrm{O}-\mathrm{M}$ vibration peaks were low compared to the pristine form and was due to the deterioration in the structure of LDH. At $\mathrm{pH} \mathrm{8,} \mathrm{the} \mathrm{Raman} \mathrm{spectrum}$ was found like that of the pristine LDH. An increase in the intensity of band centered at 1104 $\mathrm{cm}^{-1}$ was attributed due to the peaks of adsorbed $\mathrm{PO}_{4}{ }^{3-}$ which appears in the range of 
900-1200 $\mathrm{cm}^{-1}$ and thus broadened the band [88]. The Raman spectra shows a sharp band at $1064 \mathrm{~cm}^{-1}$ which indicates the symmetric $\mathrm{C}-\mathrm{O}$ stretching vibrations of car bonates/bicarbonates in the interlayer space of $\mathrm{LDH}$ reference samples, followed by bands of low intensity at 986 and $688 \mathrm{~cm}^{-1}$ confirms the presence of bicarbonates in the $\mathrm{Mg} / \mathrm{Al} \mathrm{LDH}$ samples with high molar ratio [88]. However, the intensive, sharp bands at $\sim 670 \mathrm{~cm}^{-1}$ were observed for the $\mathrm{Mg} / \mathrm{FeLDH}$ samples. Broadbands at $\sim 1600 \mathrm{~cm}^{-1}$ and $1330 \mathrm{~cm}^{-1}$ were ascribed due to the carbonates in the $\mathrm{Mg} / \mathrm{Al}$ and $\mathrm{Mg} / \mathrm{Fe} \mathrm{LDH}$ samples, respectively. It is worth to mention that the bands related to carbonates in the $\mathrm{Mg} / \mathrm{Fe} \mathrm{LDH}$ samples had a high intensity and indicated a different nature of interlayer anions in comparison to the $\mathrm{Mg} / \mathrm{Al} \mathrm{LDH}$ samples.

\subsection{DTA-TGA Characterization of Zn-Al LDHs Catalysts}

The DTA-TGA Technique Characterizes materials by Measuring Changes in Mass as a function of Temperature. Thermogravimetric analysis (TGA) is widely used in materials science stream together with DSC, TMA, and DMA. TGA measures the mass of a sample while the sample is heated or cooled in different atmosphere. The DTA-TGA analysis of Zn$\mathrm{Al} \mathrm{LDHs}$ was characterized in order to evaluate the disappearance of $\mathrm{H}_{2} \mathrm{O}$ molecules, and other intercalated groups such $\mathrm{CO}_{3}, \mathrm{NO}_{3}, \mathrm{SO}_{4}{ }^{2-}$ an anionic groups when heated at high temperatures [89]. It was observed that the weight loss was due to the incorporated molecule which had been burnt. The thermogravimetric analysis of the synthesized LDHs shows that the TGA-DTA patterns were characterized by a weight loss between 10 and $14 \%$ due to the loss of the interlayer water in the temperature range of $50-250{ }^{\circ} \mathrm{C}$. For $\mathrm{Zn}-\mathrm{Al}-\mathrm{CO}_{3}$ there are two steps that takes place during dehydration at $150{ }^{\circ} \mathrm{C}$ and $250{ }^{\circ} \mathrm{C}$. These steps are due to the loss of adsorbed and interlayer water followed by water loosely coordinated to the interlayer carbonate. However, the interlayer carbonate is released as $\mathrm{CO}_{2}$ at approximately 350 ${ }^{\circ} \mathrm{C}$. The total mass loss was $20.86 \%$. For $\mathrm{Zn}-\mathrm{Al}-\mathrm{NO}_{3}$, there are mass losses at 150, 250, 350 and $450{ }^{\circ} \mathrm{C}$. The mass losses at 150 and 250 are escorted by a change in the heat flow; it was resulted from the removal of the adsorbed surface water and the interlayer water [89]. The second distinct mass loss in the temperature range of $350-460{ }^{\circ} \mathrm{C}$ results from two steps, such as the dehydroxylation of the
$\mathrm{Zn}-\mathrm{Al}-\mathrm{LDH}$ layers and the decomposition of the interlayer $\mathrm{NO}_{3}{ }^{-}$anions. The total mass loss were around $21.5 \%$. TGA-DTA analysis for $\mathrm{Zn}-\mathrm{Al}-\mathrm{Cl} \mathrm{LDH}$ shows similar dehydration behaviour compared with $\mathrm{Zn}-\mathrm{Al}-\mathrm{NO}_{3}$, but $\mathrm{Cl}$ was lost in the temperature range of $400-500{ }^{\circ} \mathrm{C}$. The total mass loss at $700{ }^{\circ} \mathrm{C}$ was $18.84 \%$. The decomposition of $\mathrm{Zn}-\mathrm{Al}-\mathrm{SO}_{4}$ occurred in the following steps: the first mass loss at $150{ }^{\circ} \mathrm{C}$ matched to the evaporation of surface-adsorbed water followed by evaporation of the interlayer water at $250{ }^{\circ} \mathrm{C}$; a third loss of mass occurring at $350{ }^{\circ} \mathrm{C}$ was ascribed due to the dehydroxylation of the brucite-like octahedral layers. The fourth step at $600{ }^{\circ} \mathrm{C}$ was likely due to the elimination of the intercalated $\mathrm{SO}_{4}{ }^{2-}$ in the $\mathrm{Zn}-\mathrm{Al}$ LDH interlayers [89]. DTA-TGA analysis shows whether the anions are decomposed in the interlayer of $\mathrm{LDHs}$.

\subsection{XRD Characterization of $\mathrm{LDHs}$}

XRD is an instrument is used to characterize the nature of the LDHs such as crystalline or amorphous. The XRD analysis is done with an X-ray source of $\mathrm{Cu}-\mathrm{K}_{\alpha}$ radiation $(\lambda=1.5406$ $\AA$ ). It will analyze and identify the unknown crystalline compounds by Brag Brentano method. The diffractogram of the precursor material $\left(\mathrm{Mg}_{2} \mathrm{AlCO}_{3}-\mathrm{LDH}\right)$ shows both sharp and symmetrical peaks and some high angle asymmetrical peaks; this provides proof of well crystallized and ordered layered structure of $\mathrm{Mg}_{2} \mathrm{AlCO}_{3}-\mathrm{LDH}$. The characteristic pattern of hydrotalcite is present, to be precise a set of four reflection lines at $2 \theta=10,20.00,38.56$ and $61.00^{\circ}$ were due to the reflections of the sharp and basal planes corresponding to the (003), (006), and (009). With broad reflections for (015) and broad reflections for (110) are defined due to the crystalline patterns respectively. The XRD reflections for LDH samples are usually indexed using a hexagonal cell with rhombohedral symmetry $\mathrm{R}-3 \mathrm{~m}$. Said et al. [90] reported that the for $\mathrm{Mg}-\mathrm{Al} \mathrm{CO} \mathrm{CO}_{3} \mathrm{HT}$ calcined samples at $450{ }^{\circ} \mathrm{C}$, the X-ray patterns of the calcined materials, observed two new intensive diffractions lines at around 43.1 and $62.5^{\circ}$, which correspond to the (200) and (220) reflections of the $\mathrm{MgO}$ periclase-type structure [90]. Diffraction peaks of brucite matched with a standard pattern (JPCDS No. 98-003-4961) [91]. The (003) sharp intense strong peak were attributed due to the crystallinity of $\mathrm{LDHs}$ formed, and the remaining peaks were not intense this could be due to the $\mathrm{PH}$ parameter during the synthesis of $\mathrm{LDH}$. The $\mathrm{Mg}_{2} \mathrm{AlCO}_{3}$ $\mathrm{LDH}$ spacing (that is, the thickness of a layer 
plus the interlayer space) is $8.77 \AA$, value greater than that of a hydrotalcite of this type which is normally 7. $65 \AA$ [91]. XRD of MMgAlO reported by Marcu et al. [92] that the MMgAlO samples calcined at $550{ }^{\circ} \mathrm{C}$ displayed, in all the cases, the same peaks at $2 \theta 43.5$ and $63^{\circ}$ than the $\mathrm{MgAlO}$ mixed oxide which corresponded to the (200) and (220) reflections of the periclase-like structure (JCPDSICDD 4-0829). However, weak reflections that can correspond to both $\mathrm{Fe}_{2} \mathrm{O}_{3}$ (JCPDS 39-1346) and $\mathrm{FeAl}_{2} \mathrm{O}_{4}$ (JCPDS 34-0192) phases whose peaks are superimposed, were observed for FeMgAlO catalyst. No segregated phases were observed in the other samples suggesting that the mixed oxides were solid solutions containing the transition metal cations [92].

\subsection{BET Surface Area of LDHs}

Brunauer-Emmett-Teller (BET) theory aims to explain the physical adsorption of gas molecules on a solid surface and serves as the basis for an important analysis technique for the measurement of the specific surface area of materials. The observations are very often referred to as physical adsorption or physisorption. The surface area $\left(S_{\mathrm{BET}}\right)$ of the samples were determined using BET (Brunauer, Emmett and Teller) model. The total volumes were calculated according to the amount of nitrogen $\left(\mathrm{N}_{2}\right)$ absorbed at a relative pressure $\left(\mathrm{P} / \mathrm{P}_{0}\right)$ of 0.99. The pore volumes were calculated from the desorption branch of the isotherms using the Barrett-Joyner-Halenda (BJH) method, for the pores between 1.7 and $300.0 \mathrm{~nm}$. It was clearly observed that the $S_{\text {BET }}$ of (TUC-LDHs) is the highest of $235.3 \mathrm{~m}^{2} / \mathrm{g}$ compared to 198.7 $\mathrm{m}^{2} / \mathrm{g}$ for "T-mixer" (TU-LDHs) and $148.1 \mathrm{~m}^{2} / \mathrm{g}$ for CC-LDHs as well as the pore sizes (90.83 $\AA$ ) and highest pore volume $\left(0.48 \mathrm{~cm}^{3} / \mathrm{g}\right)$. Both of "T-mixer" Pretreatment followed by conventional co-precipitation (TUC-LDHs) and Conventional coprecipitation (CC-LDHs) facilitates the macrostructure of pores. However, the TU-

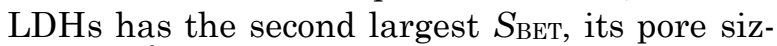
es $(24.4 \AA)$ and pore volume $\left(0.08 \mathrm{~cm}^{3} / \mathrm{g}\right)$ are the lowest in comparison with other two materials. This indicates that the TU method contributes to the formation of mesoporous structure.

The increase in surface area of TU-LDHs is likely caused by the enhanced micromixing in the 'T-mixer', where the use of ultrasonication can intensify the turbulent eddies and those microbubble bursting that erode the surface area of layered structure through removal of the interlayer anions [93]. Said et al. [94] reported that the $\mathrm{Mg} \mathrm{Al} \mathrm{Ht}$ carbonate shows BET sur- face area of $\mathrm{Mg}_{2} \mathrm{Al}-\mathrm{CO}_{3} \mathrm{HT}-75 \mathrm{Mg}_{2.5} \mathrm{Al}-\mathrm{CO}_{3}$ HT-93, $\mathrm{Mg}_{3.0} \mathrm{Al}-\mathrm{CO}_{3} \mathrm{HT}-105, \mathrm{Mg}_{3.5} \mathrm{Al}-\mathrm{CO}_{3}-101$ $\mathrm{HT}, \mathrm{Mg}_{4.0} \mathrm{Al}-\mathrm{CO}_{3} \mathrm{HT}-56$, from these surface it is evident that on calcination, the disappearance of water and carbonates leads to a considerable increase in the surface area and volume of the pores ranging from 0.33-0.61 [94].

\section{8 $\mathrm{N}_{2}$-Adsorption-desorption of $\mathrm{MgAl} \mathrm{LDHs}$}

A plot of relative pressure vs volume adsorbed obtained by measuring the amount of $\mathrm{N}_{2}$ gas that adsorbs onto the surface of catalysts i.e. sorbate, and the subsequent amount that desorbs at a constant temperature. $\mathrm{N}_{2}$ adsorption-desorption isotherm of $\mathrm{MgAl} \mathrm{LDHs}$ for all the adsorbents show a Type IV isotherm according to the IUPAC classification, which is connected with mesoporous materials [95]. TUC-LDHs and CC-LDHs shows a H3 type hysteresis loop, signifying that the pores are produced by 'slit-shaped' of plate-like particles [95]. This type of isotherm is generally observed in the mesoporous stacking structure of sheet-like $2 \mathrm{D}$ crystallites [95]. In the case of TU-LDHs, it shows a H2 type hysteresis loop corresponding to a complex and interconnected pore structure, indicating that the pores are produced by rapid nucleation process.

The surface area $\left(S_{\mathrm{BET}}\right)$ of the samples were determined using BET (Brunauer, Emmett and Teller) model. The total volumes (V Total) were calculated according to the amount of nitrogen $\left(\mathrm{N}_{2}\right)$ absorbed at a relative pressure $\left(\mathrm{P} / \mathrm{P}_{\mathrm{O}}\right)$ of 0.99. The pore volumes were calculated from the desorption branch of the isotherms using the Barrett-Joyner-Halenda (BJH) method, for the pores between 1.7 and $300.0 \mathrm{~nm}$. It was observed clearly that the $S_{\text {BET }}$ of "T-mixer Pretreatment followed by conventional coprecpitation (TUC-LDHs) is the highest of $235.3 \mathrm{~m}^{2} / \mathrm{g}$ compared to $198.7 \mathrm{~m}^{2} / \mathrm{g}$ for TULDHs and $148.1 \mathrm{~m}^{2} / \mathrm{g}$ for conventional coprecipitation (CC-LDHs) as well as the pore sizes (90.83 $\AA$ ) and highest pore volume (0.48 $\mathrm{cm}^{3} / \mathrm{g}$ ). Both of TUC-LDHs and CC-LDHs facilitate the macrostructure of pores. However, "Tmixer" TU-LDHs has the second largest $S_{\text {BET, }}$ its pore sizes $(24.4 \AA)$ and pore volume $(0.08$ $\mathrm{cm}^{3} / \mathrm{g}$ ) are the lowest in contrast with other two materials. This attributes that the TU method contributes to the formation of mesoporous structure. The increased micromixing in the ' $\mathrm{T}$ mixer' could possibly cause the increased surface area of TU-LDHs. Here, ultrasonication can multiply the turbulent eddies and microbubble bursting erodes the surface area of hydrotalcites of layered structure while the in- 
terlayer anions are removed [95]. However, during the calcination, the departure of water and carbonates leads to a considerable increase in the surface and volume of the pores [96].

\subsection{TPR Characterization of $\mathrm{Mg} \mathrm{Al} \mathrm{LDHs}$}

Temperature Programmed Reduction (TPR) is a characterization of materials generally used in catalysis studies to characterize the surface chemistry of metals and metal oxides under varying thermal conditions. TPR-enabled mass spectrometry equipment can acquire quantitative and qualitative data relating to the reducing gas mixtures that are made to flow over metallic samples. Ibrahim [97] reported the TPR characterization of $\mathrm{MgAl} \mathrm{LDHs}$ catalysts of three samples. The peaks shifted towards lower time when the Mg content is higher. Although, the amounts of consumed $\mathrm{H}_{2}$ decreased with the increase in $\mathrm{Mg}$ content which are 3175.91765, 1395.65979, and $277.55466 \mathrm{~mol} / \mathrm{g}$, respectively. The amount of gas uptake were very little as $\mathrm{MgO}$ is difficult to be reduced. Hence, for calcined Mg-Al HTlcs or $\mathrm{MgO}$, no reduction peaks were detected until $900{ }^{\circ} \mathrm{C}$. Saikia [98] reported that the metalsupport interaction is another factor affecting the catalytic performance, of $\mathrm{Ru}-\mathrm{Mg} \mathrm{Al} \mathrm{LDHs}$ catalysts which was analysed by $\mathrm{H}_{2}$-TPR. However, for the control experiment using the commercial $\mathrm{RuO}_{2}$ catalyst, only one reduction peak at $213{ }^{\circ} \mathrm{C}$ was observed, corresponding to the reduction of $\mathrm{Ru}^{4+}$ to $\mathrm{Ru}^{\circ}$. However, the 2.5\% $\mathrm{Ru} / \mathrm{MgAl}$ catalysts, TPR results indicated that, in general, the metal-support interaction becomes stronger with an increase in the reduction temperature.

In the case of the as prepared $\mathrm{RuCl}_{3} / \mathrm{MgAl}$ $\mathrm{LDH}$, the peak at $126{ }^{\circ} \mathrm{C}$ can be assigned for the reduction of $\mathrm{RuCl}_{3}$ adsorbed on the surface of $\mathrm{MgAl} \mathrm{LDH}$ [98]. For the reduced 2.5\% $\mathrm{Ru} / \mathrm{MgAl}$ catalysts, three reduction peaks centred at $120-180{ }^{\circ} \mathrm{C}$ (peak I), $185-220^{\circ} \mathrm{C}$ (peak II), and $320-340{ }^{\circ} \mathrm{C}$ (peak III), which was ascribed due to the weakly supported $\mathrm{RuOx}$ species on the support, strongly supported RuOx species and the surface or subsurface oxygens, respectively [98]. With $2.5 \% \mathrm{Ru} / \mathrm{MgAl}$ catalysts was reduced at $160-300{ }^{\circ} \mathrm{C}$, the peak gradually

Methanation of i) $\mathrm{CO}$ and ii) $\mathrm{CO}_{2}$

i) $\mathrm{CO}+3 \mathrm{H}_{2} \rightleftharpoons \mathrm{CH}_{4}+\mathrm{H}_{2} \mathrm{O}, \Delta \mathrm{H}^{\circ} 298=-206 \mathrm{~kJ} / \mathrm{mol}$

ii) $\mathrm{CO}_{2}+4 \mathrm{H}_{2} \rightleftharpoons \mathrm{CH}_{4}+2 \mathrm{H}_{2} \mathrm{O}, \Delta \mathrm{H}^{\circ} 298=-165 \mathrm{~kJ} / \mathrm{mol}$

Figure 2. $\mathrm{CO}_{2}$, $\mathrm{CO}$ methanation reactions [99]. shifted to higher values from $135^{\circ} \mathrm{C}$ to $175^{\circ} \mathrm{C}$, suggesting that the improved metal-support interaction promoted with the increase in reduction temperature $\left(<300{ }^{\circ} \mathrm{C}\right)$. Interestingly, when the $\mathrm{Ru} / \mathrm{MgAl}$ catalysts were reduced at high temperatures, namely $>400{ }^{\circ} \mathrm{C}$, the peak I shifted back to $120{ }^{\circ} \mathrm{C}$ with a shoulder peak was observed at $132^{\circ} \mathrm{C}$, suggesting the reduced metal-LDO support interaction compared with that of metal-LDH. It was observed that the strong interaction between $\mathrm{Ru}$ species and support favours the catalysis [98]. Ateeq et al. [100] reported that the TPR for nickel containing hydrotalcite was characterized for $\mathrm{Mg}-\mathrm{Ni}$ samples of varying ratios, showed two peaks of $\mathrm{H}_{2}$ consumption. The first peak observed was at $570 \mathrm{~K}$ corresponds to the discharge of $\mathrm{NO}_{3}$ anions as $\mathrm{NO}_{2}$ and the subsequent reduction of $\mathrm{NO}$ and $\mathrm{N}_{2} \mathrm{O}$. The second peak was observed at 705,920 and $1000 \mathrm{~K}$ for respective samples for the reduction of $\mathrm{NiO}$ particles. When $\mathrm{Mg}$ content is increased the reduction of the nickel oxide decreases it can be compared with the decrease of the NiO crystal size. This behaviour is ascribed due to the formation of $\mathrm{Ni}$ aluminate band of nickel spinel type and decreasing the size the crystallite and hence it hinders their reducibility [100].

\section{Applications of LDH Catalysts}

\section{$5.1 \mathrm{CO}_{2}$ Methanation}

Among the catalytic reactions, the reduction of $\mathrm{CO}$ and $\mathrm{CO}_{2}$ with transition metal catalysts to form methane, (methanation reaction) is a favourable method for the removal of carbon oxides resulted in the manufacturing of various energy carrier products [101]. Few decades ago, methanation reactions have received substantial attention as an effective method to produce natural gas substitute, where coal is oxidized to $\mathrm{CO}$ and $\mathrm{H}_{2}$ followed by accumulation to the formation of methane. Generally, methanation

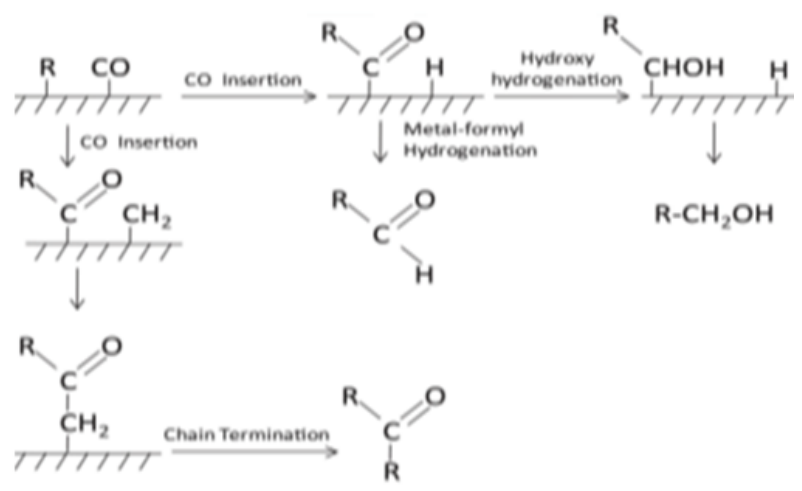

Figure 3. $\mathrm{C}_{2}$ oxygenates by Fischer-Tropsch synthesis of carbene [101]. 
reaction is applied in ammonia plants at the final stages of purification for the synthesis gas insitu with the formation of low concentrations of $\mathrm{CO}$ and $\mathrm{CO}_{2}$ at $0.1-0.5 \%$ are catalytically removed in the presence of hydrogen (Figure 2). The reaction is very important due to the poisonous or synergistic outcome of carbon oxides for ammonia synthesis reported by Xavier et al. [102]. Further, Xavier et al. [102] reported that the $\mathrm{CO}_{2}$ methanation reaction with $\mathrm{M}^{2+}$ and $\mathrm{M}^{3+}$ cations, with their proportion, with wide range of $\mathrm{LDH}$ compositions are obtained, which addresses methanation reaction as potential process to produce fine chemicals.

Santos et al. [103] reported synthesis of Co$\mathrm{Al} \mathrm{LDHs}$ nano sheets produces selective oxygenates, of $\mathrm{C}_{2}$ oxygenates, for Fischer-Tropsch synthesis of carbene insertion (Figure 3). Figure 3 represents the Fischer-Tropsch synthesis of carbene for the formation of oxygenates [103].

\subsection{Cyanoethylation Reaction}

Octavian et al. [104] reported cyanoethylation with $\mathrm{LDHs} \mathrm{MMgAlO}$ catalysts $(\mathrm{M}=\mathrm{Mn}$, $\mathrm{Fe}, \mathrm{Co}, \mathrm{Ni}, \mathrm{Cu}$ or $\mathrm{Zn}$ ). The results of the catalytic cyanoethylation reaction of methanol with LDH catalysts exhibited high selectivity of 99$100 \% \quad$ in $\quad \beta$-metoxypropionitrile $\left(\mathrm{CH}_{3}-\mathrm{O}-\mathrm{CH}_{2}-\mathrm{CH}_{2}-\mathrm{CN}\right)$, while the conversions were very low. The latter remained in all cases lower than $5 \%$ after $5 \mathrm{~h}$ of reaction and ranked as follows: $\mathrm{MgAl}-\mathrm{LDH}>\mathrm{CoMgAlLDH} \approx \mathrm{CuM}$ gAl-LDH $\approx$ MnMgAl-LDH $>$ FeMgAl-LDH $\approx$ ZnMgAl.LDH > NiMgAl-LDH. The cyanoethylation reaction with $\mathrm{MgAl} \mathrm{LDH}$ conversions were lower i.e $\sim 20 \%$ at $5 \mathrm{~h}$ with ethanol. This is attributed due to the proton abstraction which is easier on methanol with higher acidic character than ethanol which was not the rate limiting step [104]. However, with the lower conversions values observed for $\mathrm{MMgAl}-\mathrm{LDH}$ compared to the MgAl-LDH sample must be related to the lower intrinsic basic character of the former samples which decreased their ability to abstract a proton from the hydroxyl group of methanol. That was ascribed due to the higher electronegativity of the transition metal cations than $\mathrm{Mg}^{2+}$ which decreased the electron density on the hydroxyl groups of the

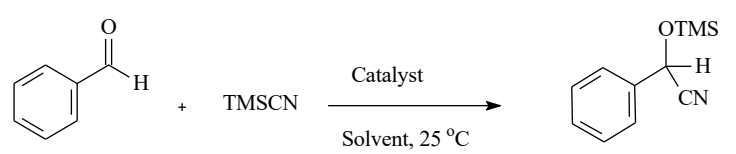

Figure 4. $\mathrm{MgAlCu} \mathrm{LDHs}$ is used for cyanosilylation of carbonyl compounds [91].
MMgAl-LDH layers. Assuming that the latter are the catalytic sites, due to which their activity decreased.

\subsection{Cyanosilylation of Aldehydes}

Fahimeh et al. [105] reported that the cyanosilylation of aromatic aldehydes with MgAl$\mathrm{Cu}$ LDHs catalysts (Figure 4). These catalysts have been tested in different organic transformations in recent years reported by Choudhary et al. [71]. Fahimeh et al. [105] reported the catalytic activity in different parameters such as percentage of catalysts employed, catalyst loading and effect of solvent for cyanosilylation at room temperature were evaluated. $20 \mathrm{~mol} \%$ of LDHs catalyst were effective for cyanosilylation in dichloromethane solvent with quantitative yield in 30 minutes duration of time (Figure 4).

\subsection{Oxidation of Alcohols with $\mathrm{Ni}-\mathrm{Al}$}

Rahman et al. [106] reported for the first time reported a shortest route for molecular oxygen activation by $\mathrm{Ni}-\mathrm{Al}$ hydrotalcite for selective oxidation of various substituted a-ketols, benzylic and allylic alcohols to carbonyl compounds. They studied the comparison of Cat A, Cat B and Cat C with Ni-Al ratios of 2:1, 2.5:1 and $3: 1$ and found that the best results with $\mathrm{Ni}-\mathrm{Al}$ 2:1 ratio. Cat $\mathrm{B}$ with $\mathrm{Ni}-\mathrm{Al}$ ratio of 2.5:1 was synthesized by co-precipitation method with ammonia as base. All these catalysts were subjected to longer duration of time for the reaction compared to Cat $\mathrm{A}$ with $2: 1 \mathrm{Ni}-\mathrm{Al}$ ratio which took $6 \mathrm{~h}$ for the completion of reaction. Other ratios 2.5:1 and 3:1 Ni-Al took 10 to $20 \mathrm{~h}$ for the completion of reaction. This is ascribed due to the formation of more $\mathrm{Ni}$ ions during the preparation of catalysts. One of the notable achievements of this methodology was Cinnamyl alcohol was oxidized to Cinnamaldehyde without disturbing the double bond [106].

5.5 Reduction of Aldehydes to Alcohols with Ni$\mathrm{Al}$

Choudhary et al. [71] have reported with different ratios of $\mathrm{Ni}$-Al hydrotalcites were used in the reduction of aromatic, heterocyclic aldehydes to alcohols. Different moieties of aro-

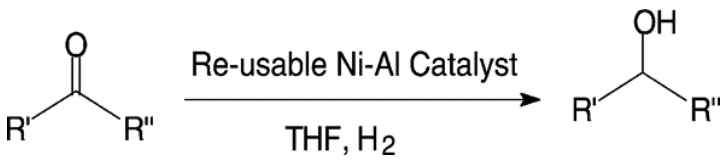

Figure 5. Ni-Al hydrotalcite calcined catalyst for reduction of aldehydes to alcohols [71]. 
matic and conjugated aldehydes, and heterocyclic aldehydes were subjected for the reduction of aldehydes to alcohols selectively in the presence of other susceptible functional groups. Figure 5 equation (4) shows the reported Cinnamaldehyde that was reduced to Cinnamyl alcohol without affecting the double bond. Hence, it is well known that $\mathrm{Ni}$ catalyst reduces the double bond in aliphatic and aromatic compounds.

Rahman et al. [107] reported the reduction of aromatics to alicyclic molecules with super active 2:1 Ni-Al hydrotalcite catalysts to alicyclic without loss of activity of the catalysts. Osmate intercalated hydrotalcite aimed at selective oxidative bromination of bisphenol-A for asymmetric dihydroxylation of olefins [108] with NMO (N-Methylmorpholine N-oxide) used as co-oxidant in company of molecular oxygen was reported by Choudhary et al. [108].

\subsection{Reductive Amination of Benzaldehyde with $\mathrm{Ni}-\mathrm{Al} \mathrm{LDHs}$}

Rahman et al. [106] reported the reductive amination of benzaldehyde with ratios of $2: 1$, 2.5 and 3:1 Ni-hydrotalcite catalysts which exhibited good catalytic activity for synthesis of amines. Ni-hydrotalcite catalysts for reductive amination of benzaldehyde with $\mathrm{NaBH}_{4}$, acts as reducing agent to form in situ-Ni-boride which is generated swiftly in the formation of desired product at room temperature. The activity of $\mathrm{Ni}-\mathrm{Al}$ hydrotalcites for organic transformation discussed above is attributed due to the even distribution of $\mathrm{Ni}$ ions for $2: 1$ ratio of $\mathrm{Ni}-\mathrm{Al}$ hydrotalcite catalysts and inactivity of 2.5:1, and $3: 1$ ratio catalyst is due to higher content of $\mathrm{Ni}$ in Ni-Al hydrotalcite [107].

\section{7 $\mathrm{NO}_{\mathrm{x}}$ Reduction}

$\mathrm{Cu} / \mathrm{Co} / \mathrm{M}$ (where $\mathrm{M}=\mathrm{Al}, \mathrm{Fe}, \mathrm{Cr}, \mathrm{Ni}$ and $\mathrm{Fe}$ ) mixed oxides and Mn-LDHs have been studied for NOx reduction to evaluate the catalytic activity of mixed metal oxides. Polmeres et al. [109] reported selective reduction with mixed oxides at high temperatures resulting from LDHs. Numerous methods have been used for the reduction of $\mathrm{NO}_{\mathrm{x}}$ emission. Primarily the conventional procedures for $\mathrm{NO}_{\mathrm{x}}$ reduction with $\mathrm{NH}_{3}$ (ammonia-SCR) [109]. SCR of $\mathrm{NO}_{\mathrm{x}}$ is an extremely efficient method to reduce $\mathrm{NO}_{\mathrm{x}}$ emissions in oxygen-rich exhausts. In the area of $\mathrm{NO}_{\mathrm{x}}$ reduction, mixed metal oxides based catalysts have been extensively studied due to high hydrothermal stability of LDHs catalysts [109]. Nonetheless, the ammonia-SCR is nonenvironment friendly process. Hydrocarbon acts as excellent reductant for $\mathrm{NO}_{\mathrm{x}}$ (HC-SCR) that entices more interests due to its short price [109]. The emergence of LDHs, catalysts generated potential interests as catalysts for removal of $\mathrm{NO}_{\mathrm{x}}$ from diesel exhaust gases [109]. LDHs have exhibited excellent catalytic activities on SCR of $\mathrm{NO}_{\mathrm{x}}$ in the presence of $\mathrm{SO}_{2}$ and $\mathrm{H}_{2} \mathrm{O}$ at low temperature. Palomares et al. [109] have reported that the behavior of soot combustion with $\mathrm{NO}_{\mathrm{x}} / \mathrm{O}_{2}$ with potassiumsupported Mg-Al hydrotalcite with in situ FTIR spectroscopic studies confirmed the presence of $\mathrm{NOx}$ in $\mathrm{O}_{2}$ favors the combustion of soot at lower temperatures $(<573 \mathrm{~K})$ [110]. Adamski et al. [110] reported that the $\mathrm{nFeO}_{\mathrm{x}} @ \mathrm{TiO}_{2}$ catalysts possessing the core-shell structure demonstrates that the excellent catalytic activity on SCR of $\mathrm{NO}_{x}$ with $\mathrm{NH}_{3}$ which acts as reductant [110].

\subsection{Polymerization of Propylene Oxide with LDHs Catalysts}

Olena et al. [111] reported for the first time that LDHs as heterogeneous catalysts for polymerization of propylene oxide. Does not require complex post-reaction separation of the catalyst. Laycock et al. [112] reported polymerization of Propylene oxide with thermally activated synthetic MgAl LDHs. Meanwhile, in similar conditions, yields an optically active crystalline fraction and a liquid fraction of considerably reduced optical activity. Both liquid fractions exhibit a high degree of regionirregularity in the polymer chain [112].

\subsection{Ring Opening Reaction of Styrene Oxide with LDHs Catalysts}

Kantam et al. [72] reported the ring opening of styrene oxide with nucleophiles $\mathrm{TMeSiN}_{3}$, $\mathrm{TMeSiCN}$, and $\mathrm{MgAlCO}_{3}$ hydrotalcite catalysts which resulted in ring opening products with high conversion and selectivity. $\mathrm{MgAlCO}_{3}$ hydrotalcites displayed reusability up to 3 cycles with high reproducibility, which exhibits the good catalytic activity of $\mathrm{MgAlCO}_{3}$ hydrotalcite for ring opening of epoxides.

Tengfei Li et al. [113] reported the catalytic activity of $\mathrm{Zn}_{3} \mathrm{Al}-\mathrm{CoW}_{12}$ for aminolysis of epoxides. They further reported that the aminolysis of styrene oxide with aniline did not proceed in the absence of a catalyst while a small amount of aminolysis product $(<8 \%)$ is obtained in the presence of $\mathrm{Zn}_{3} / \mathrm{Mg}_{3} \mathrm{Al}-\mathrm{NO}_{3}$ as a catalyst. The $\mathrm{K}_{5} \mathrm{CoW}_{12} \mathrm{O}_{40}$ cluster demonstrated the higher catalytic activity, in comparison to $\mathrm{Na}_{3} \mathrm{PW}_{12} \mathrm{O}_{40}$ and $\mathrm{K}_{4} \mathrm{SiW}_{12} \mathrm{O}_{40}$ with similar structure. These results reveal the superior performance of the 
$\mathrm{CoW}_{12}$ anions for the catalytic aminolysis of epoxides with aniline and subsequent formation of B-amino alcohol-based products. Particularly, the utilization of the $\mathrm{Zn}_{3} \mathrm{AlCoW}_{12}$ as heterogeneous catalyst, demonstrated good catalytic activity although seems that the diffusion and mass transfer have an influence on the activity of the heterogeneous reaction to some extent. This may be ascribed due to the regular porous structure of the intercalation material which induces enhanced accessibility and shorter diffusion pathways during the course of the catalytic reaction [113].

\subsection{Ester Epoxidation with LDHs Catalysts}

Ester epoxidation has been reported in literature with solid catalysts intercalated with metalloporphyrins, methyl rhenium trioxide, zeolites and aluminium-based catalysts [114115] were active catalysts for epoxidation of FAMEs. Li et al. [116] reported the use of phos-

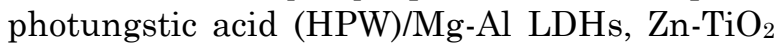
$\mathrm{LDHs}$ as active catalysts for epoxidation of FAMEs in Table 2 [116].
5.11 Suzuki Coupling Reaction with LDHs Catalysts

Several LDHs modified photo catalysts have been developed in the past for various reactions [117,118]. On contrary, a novel active LDHs photo catalysts which meets the current technical requirements by doping/deposition of various noble metals on LDHs. From the above considerations $\mathrm{LDH}$ s photocatalysts meets the criteria for the better investigation in the area of solar energy. AuPd alloy loaded on $\mathrm{ZnCr}$ $\mathrm{LDHs}$ have been prepared for reduction reaction. $\mathrm{ZnCr}$-LDHs has emerged as superior catalysts and has developed as a super active catalyst for Suzuki coupling reaction [118]. Parida et al. [117,118] reported that the synthesis of LDH@AuPd and LDH@Pd: Zn-Cr LDHs by coprecipitation method with a molar ratio of $3: 1$ at $\mathrm{pH}$ 11. Sahoo et al. [119] however, reported the synthesis of APTES functionalized LDHs.

Parida et al. [117,118] reported that the photo catalytic reaction of Suzuki coupling with LDH@AuPd catalyst. The biphenyl yield increases frequently with the effect of time after $2 \mathrm{~h}$ of irradiation. Hence, biphenyl product

Table 2. Epoxidation of FAMES with $\mathrm{H}_{2} \mathrm{O}_{2}$ conversion and selectivity [116].

\begin{tabular}{clcc}
\hline No & Catalyst & Conversion (\%) & Selectivity (\%) \\
\hline 1 & HPW-Zn-Ti LDH & 85.4 & 82.2 \\
2 & HPW-Zn-Ti-3 LDH & 90.6 & 86 \\
3 & HPW-Zn-Ti-4 LDH & 87.1 & 79.5 \\
4 & HPW-Zn-Al-3 LDH & 63.4 & 20.2 \\
5 & Zn-Ti-2 LDH & 52.2 & 8.1 \\
6 & $\mathrm{Zn}-\mathrm{Ti}-3 \mathrm{LDH}$ & 55.1 & 9.2 \\
7 & $\mathrm{Zn}-\mathrm{Ti}-4 \mathrm{LDH}$ & 56.3 & 8.4 \\
8 & $\mathrm{Zn}(\mathrm{OH})_{2}$ & 4.8 & 16.5 \\
9 & $\mathrm{Ti}(\mathrm{OH})_{2}$ & 2.9 & 23.4 \\
10 & $\mathrm{Na}_{3}\left[\mathrm{PW}{ }_{12} \mathrm{O}_{40}\right]$ & 17.8 & 8.2 \\
\hline
\end{tabular}

* Reaction temperature $-70^{\circ} \mathrm{C}$; reaction time - $7 \mathrm{~h} ; n\left(\mathrm{H}_{2} \mathrm{O}_{2}\right) / n$ (double bond), $1.5: 1 ;$ m-catalyst/m (reactants), $0.07: 1$.

Table 3. A comparison of heterogeneous Pd based catalysts reported in the previous reports with our study towards Suzuki cross-coupling reactions [117-119].

\begin{tabular}{clcc}
\hline Entry & Catalysts & Conditions $\left(\mathrm{h},{ }^{\circ} \mathrm{C}\right)$ & Conversion $(\%)$ \\
\hline 1 & XLPd & 115 & 86 \\
2 & 0.01 mol\% Pd-CD & $24 \mathrm{~h}, 60$ & 100 \\
3 & PdTNs & 1 day, 20 & 100 \\
4 & Pd/MCM-41 & $5 \mathrm{~h}, 78$ & 93 \\
5 & LDH-DS-Pd & $5 \mathrm{~h}, 80$ & 93 \\
6 & Silica-APTS-Pd & $2 \mathrm{~h}, 100{ }^{\circ} \mathrm{C}$ & 99 \\
7 & Pd@LDH in the present & $10 \mathrm{~h}, 80{ }^{\circ} \mathrm{C}$ & 96 \\
8 & AuPd bimetallic alloy NPs & $2 \mathrm{~h}$, Room temp, & 98 \\
\hline
\end{tabular}


is formed with a maximum of $98 \%$ yield. To optimize the quantity of catalysts, a series of LDH@AuPd photo catalysts were executed and was observed that the catalytic activity with $0.1 \mathrm{~g}$ was excellent (Table 3).

\subsection{Esterification with LDHs Catalysts}

2-Ethylhexanol is converted on acidic and basic sites of $\mathrm{LDHs}$ catalysts to desired products. For example, the oxidation of 2ethylhexanol to 2-ethylhexanal [120] usually takes place on acid-base sites of catalysts [121] with a minimum content of Al [121]. Successively, 2-ethylhexanoic acid to 3-heptanone [121] is achieved via Ketonization on active sites of LDHs catalysts [122]. Moreover, 3heptanol is formed by the reduction of 3heptanone over basic sites of LDHs [121,122]. It could be observed that all the reactions are directed by the properties of acidic and basic sites of catalysts. Hence, mixed oxide catalysts that are derived from LDHs are more favorable catalysts for many reactions that is easily modified and tuned by changing their elemental compositions.

\subsection{Electrodeposition Reaction with LDHs Catalysts}

The electrodeposition process is frequently used to formulate a self-supported LDHs films on conductive substrates in a two- or threeelectrode alignment. The substrate is active as working electrode, whereas an aqueous solution comprising of metal salts performs as an electrolyte in this method. Hence, the reduction reaction between the metal and $\mathrm{OH}^{-}$ions leads to the creation of a self-supported $\mathrm{LDH}$ s nano catalysts on the substrate. This method is simple, and eco-friendly process which is completed within few minutes [123,124].

\subsection{Oxygen Evolution Reaction (OER)}

Recently research has been focused on supported LDHs for OERs [123,124]. Hence, hydrogen production by electrochemical water split-

$$
\begin{gathered}
\mathrm{OH}^{-}+* \rightarrow \mathrm{OH}^{*}+\mathrm{e}^{-} \\
\mathrm{OH}^{*}+\mathrm{OH}^{-} \rightarrow \mathrm{O}^{*}+\mathrm{H}_{2} \mathrm{O}+\mathrm{e}^{-} \\
\mathrm{OH}^{-}+\mathrm{O}^{*} \rightarrow \mathrm{OOH}^{*}+\mathrm{e}^{-} \\
\mathrm{OOH}^{*}+\mathrm{OH}^{-} \rightarrow \mathrm{O}_{2}+*+\mathrm{H}_{2} \mathrm{O}+\mathrm{e}^{-}
\end{gathered}
$$

Scheme 1. Reaction of OER process in alkaline media $[123,124]$. ting is very effective and provides a greener method compared with traditional process of steam-reforming method which produces hydrogen from the natural gas $[125,126]$. Generally, the OER reaction is divided into three successive stages: adsorption of water molecules on surface of catalyst, water splitting reaction into molecular oxygen by intricate process, and finally the release of molecular oxygen [127]. Subsequently, LDHs material can dissolve in acidic conditions, they are carried out in $\mathrm{KOH}$ solution. The general reaction of OER process in alkaline media are shown in Scheme 1 [128].

Scheme 1 signifies the adsorption site on the electro catalyst and $\mathrm{O}^{*}$ and $\mathrm{OH}^{*}$ denotes as adsorbed intermediates. Each step presented above in Scheme 1 creates one electron, hence, the OER process works in alkaline media by four-electron transfer. The catalytic progress of specific OER method is initially assessed by cyclic voltammetry (CV) and linear sweep voltammetry (LSV) testing method. Though, to judge the OER performance of a particular catalyst, very crucial parameters include over potential $(\eta)$, Tafel plot $(b)$, exchange current density $\left(j_{0}\right)$, and turnover frequency (TOF), are vital for this reaction [128,129]. Furthermore, OER plays a vital role in energy-conversion systems such as $\mathrm{CO}_{2}$ reduction, fuel cells, and metal-air batteries and energy-storage [130,131]. The electro catalyst, that reduces the overall potential which is essential for water splitting as a result of lowering the activation energy, which is broadly engaged to maintain the OER kinetics [131]. The conventional precious-metal-based electro catalysts such as $\mathrm{IrO}_{2}$ and $\mathrm{RuO}_{2}$ displays excellent OER reaction [131]. Rahman and co-workers [132] recently reported OER reaction review with $\mathrm{Ni} \mathrm{LDHs}$ nano platelets. Recently there have been many articles reported on water splitting which facilitates the production of hydrogen by direct route for water splitting into hydrogen and oxygen [132]. Though, the energy necessary to cleave $\mathrm{H}$ and $\mathrm{O}-\mathrm{H}$ bonds is provided by diverse power sources such as i) Electrical (current), ii) Thermal (heat), or iii) Light (electromagnetic radiation). Despite the enormous industrial applications of hydrogen, there are further possibilities for research expanding in area of water splitting with use of LDH catalysts. Among the various renewable energy technologies for hydrogen production from water splitting, photocatalytic and photo electro-chemical (PEC) methodologies has been broadly reflected as energy technologies devoid of environmental pollution $[132,133]$. 


\subsection{Nickel Based Layered Double Hydroxides} for Water Splitting

Rahman and co-workers [132] reported various NiFe-based catalysts for water splitting reaction and developed the active phase and provided a detailed mechanism of NiFe based compounds. However, there is no article till date on categorizing the structure and the pathway, both theoretically and experimentally, during OER electro catalysis [133,134]. The earliest interrelated mechanistic studies reported that the active phase of $\mathrm{Ni}(\mathrm{OH})_{2}$ or nickel oxide $\left(\mathrm{NiO}_{\mathrm{x}}\right)$ catalyzing OER. Hence, the phase transformations of $\mathrm{Ni}(\mathrm{OH})_{2}$-based electrode tracks the Bode's diagram with $\beta$-Ni( $(\mathrm{OH})_{2}$ and $\alpha$ $\mathrm{Ni}(\mathrm{OH}) 2$ altering into $\beta$-nickel oxyhydroxide $(\beta$ $\mathrm{NiOOH}$ ) and $\gamma-\mathrm{NiOOH}$ correspondingly during charging and discharging $\gamma-\mathrm{NiOOH}$ which is derived from overcharging $\beta$ - $\mathrm{NiOOH}$, whereas $\alpha$ $\mathrm{Ni}(\mathrm{OH})_{2}$ converts into $\beta-\mathrm{Ni}(\mathrm{OH})_{2}$ [134]. Various studies on the influence of $\mathrm{Fe}$ deposition on $\mathrm{Ni}$ based OER electro-catalysts was additionally evaluated by few methods, such as density functional theory (DFT) calculation and in situ spectroscopy [132-134].

\subsection{Advantages of LDHs for OER Reaction}

LDHs materials, principally Cobalt, and Nickel containing LDHs, are the most favourable materials, that shows innovative method for OER electro-catalytic performance outperforming additional non-precious metal based OER electro-catalysts. LDHs have numerous advantages in contrast to $0 \mathrm{D}$ and $1 \mathrm{D}$ materials such as bulk surface-to-bulk ratios, surface area, particle size distribution, morphology and efficient exposure of catalytic active sites.
These properties derive the catalysts as excellent LDH materials for OER reactions [134].

\section{Other Applications of LDHs}

\subsection{LDHs Catalysts as Filler in Concrete}

The carbon foot mark of concrete production industry is rapidly emerging as larger economy in South-Asian regions that are concentrating on swiftly development of infrastructure. Additionally, the conventional methods have contributed to environmental related issues for cement production [135,136]. Hence, to decrease the environmental impact of cement production, it is necessary to develop concrete infrastructure to reduce environmental related issues with longer shelf life. LDHs are used as cement additive that emerged towards the end of the $20^{\text {th }}$ century. Nevertheless, with various degradation phenomena related with the reinforced concrete models, such as steel corrosion [137,138], freeze thaw cycles [139], ice abrasion [140,141] and acid attack [142]. The LDH finally formed was applied as a chloride entrapping additive with $8.5 \mathrm{wt} \%$ dosage in cement pastes and there were enhanced chloride uptake capabilities. Hence, Yoon et al. [143] reported the positive impact of LDHs in increasing the service life of concrete structures. Yoon et al. [143] have reported the use of commercially available $\mathrm{Mg}-\mathrm{Al} \mathrm{LDH}$ and calcined at $450{ }^{\circ} \mathrm{C}$. It has been well documented that the interlayer anions in LDHs galleries could be exchanged easily with an anion molecule.

Owing to the above stated ion exchange property [144], this exclusive property portrays LDHs as a flexible material however, they can sequestration anions from the environment

Table 4. Effect of addition of $\mathrm{LDH}$ on the mechanical properties of concrete for compressive strength (CS) [145].

\begin{tabular}{|c|c|c|c|c|c|c|}
\hline \multirow{2}{*}{ LDHs } & \multirow{2}{*}{ Cement } & \multirow{2}{*}{ Dosage } & \multicolumn{2}{|c|}{ Concrete Properties } & \multirow{2}{*}{ Age } & \multirow{2}{*}{ Year } \\
\hline & & & $\mathrm{CS}$ & $\mathrm{FS}$ & & \\
\hline$\overline{\mathrm{Ca}-\mathrm{Al} \mathrm{LDHs}}$ & Cem 42.5 & $1-5 \%$ & $+6 \%(2 \% \mathrm{LDH})$ & - & $28 d$ & 2009 \\
\hline $\mathrm{MgAl} \mathrm{CO}_{3}$ & & $1-2 \%$ & inconclusive & - & $28,48 d$ & 2013 \\
\hline MgAl LDH & $8.5 \%$ & & $\sim-2 \%$ & - & $28 \mathrm{~d}$ & 2014 \\
\hline $\mathrm{MgAl}$ pAB & Cem I $42.5 \mathrm{~N}$ & $5-10 \%$ & $-17.2 \%(10 \% \mathrm{LDH})$ & $-21.38 \%(10 \% \mathrm{LDH})$ & $28 d$ & 2015 \\
\hline $\mathrm{MgAl} \mathrm{NO}_{2}$ & Cem I $42.5 \mathrm{~N}$ & $5-10 \%$ & $-14.2 \%$ & $-19.1 \%(10 \% \mathrm{LDH})$ & $28 d$ & 2015 \\
\hline MgAl LDH & & $1 \%$ & $-25 \%(28 \mathrm{~d})$ & - & $8-178 d$ & 2015 \\
\hline LiAl LDH & & $1-3 \%$ & $+25 \%$ & - & $7 d$ & 2017 \\
\hline $\mathrm{CaAl} \mathrm{NO}{ }_{3}$ & Cem I 52.5R & $0.5-2$ Vol. & $+17 \%(1 \% \mathrm{LDH})$ & $+55 \%$ & $28 \mathrm{~d}$ & 2018 \\
\hline $\mathrm{MgAl} \mathrm{CO}_{3}$ & Cem I 52.5 & $1-3 \%$ & $\sim+3.5 \%(3 \% \mathrm{LDH})$ & - & $28 d$ & 2018 \\
\hline $\mathrm{MgAl} \mathrm{LDH}$ & & $1-2 \%$ & $+8.2 \%(1 \% \mathrm{LDH})$ & - & $56 \mathrm{~d}$ & 2018 \\
\hline LiAl LDH & & $0.5-1.5 \%$ & $+46.2 \%(1 \% \mathrm{LDH})$ & - & $28 \mathrm{~d}$ & 2019 \\
\hline
\end{tabular}

${ }^{*} \mathrm{CS}=$ compressive strength, $\mathrm{FS}=$ Flexural strength 
with an option of discharging a tailored anion. LDHs are consequently used as potential additive for the imprisonment of corrosion causing types of materials and discharging of corrosion preventing anions in cementitious environments. In concrete research technology, LDHs are nanoparticles which have been reported to polish the microstructure of concrete without increase in porosity [145]. Although, LDHs is regularly added in its powdered form to be distributed in the matrix. However, these LDHs nanoparticles are homogenously distributed during cement hydration process. Hence, $\mathrm{LDHs}$ can deliver extra nucleation sites during cement hydration. This further promotes growth of CSHs gels into the cavities, thus refining the microstructure. Furthermore, these particles perform as micro-fillers inside the cementitious matrix. It is provisional on the type of $\mathrm{LDHs}$ used, which will require a positive effect on the mechanical properties, such as compressive strength (CS) of concrete (Table 4). The LDHs usually have hexagonal platelet structures. Although they are capable of retaining their structure in concrete, the resulting concrete exhibits a superior flexural strength (FS) as LDHs possess thin platelets that acts as micro-beam elements flanked by cementitious materials and as a result it helps in effective transfer of bending stresses [145]. Table 4 presents a comprehensive data on flexural strength enhancement of concrete with different types of LDHs and doses used by different authors.

\subsection{LDHs as Filler for Polymer}

There are many literature reports pertaining to montmorillonites and cationic clays, suggested on the application of organic modified hydrotalcites are efficient fillers of polymers, for example polyethylene, polystyrene and polymethylmetacrylate [146] which gave excellent results for mechanical strength [146]. Jiao [146] reported that the $\mathrm{MgAl}-\mathrm{CO}_{3}$ showed as an efficient halogen-free flame retardant additive, which performs as Heat Release Rate (HRR) reducer and as a remarkable smoke suppressant [147]. It has been reported that the $\mathrm{MgAl}-\mathrm{CO}_{3}$ has a better flame retardant efficacy than either $\mathrm{MH}$ (Magnesium hydroxide) or $\mathrm{AH}$ (Aluminium hydroxide) as flame retardation of EVA [147,148]. Costache et al. [149] reported that the phosphorus compounds act as efficient halogen free flame retardants and are often used alone or in combination with $\mathrm{MH}$ or $\mathrm{AH}$, that increases the conversion of organic matter to charred sheets during combustion. Hence, these charred sheets will lower the amount of flammable volatile gases that reaches the flame zone and reduces the heat transfers from the flame to the polymer.

Prasad et al. [150] reported that magnetic $\mathrm{Fe}_{3} \mathrm{O}_{4}$ based LDHs nanocomposites $\left(\mathrm{Fe}_{3} \mathrm{O}_{4} / \mathrm{LDHs}\right)$ on the synthesis, properties and applications. Generally, the properties of optimal magnetic $\mathrm{Fe}_{3} \mathrm{O}_{4} / \mathrm{LDH}$ shotocatalytic assembly aim to come across the following requirements. (i) The preparation and manufacturing process of $\left(\mathrm{Fe}_{3} \mathrm{O}_{4} / \mathrm{LDHs}\right)$ are very simple with good yield. (ii) Magnetic $\mathrm{Fe}_{3} \mathrm{O}_{4}-\mathrm{LDHs}$ composites exhibits greater photocatalytic performance of $\mathrm{Fe}_{3} \mathrm{O}_{4}$ and pure $\mathrm{LDHs}$ sample. (iii) Magnetic $\mathrm{Fe}_{3} \mathrm{O}_{4} / \mathrm{LDHs}$ photo catalysts should be reprocessed through exterior magnetic field which can be easily regenerated and recycled. Finally, the $\mathrm{Fe}_{3} \mathrm{O}_{4} / \mathrm{LDHs}$ photo catalyst possesses an outstanding photo corrosion resistance capacity and should be very stable at room temperature. Daud et al. [151] have reported that the graphene/LDHs nanocomposites have emerged as new advances in the area of material science. Here, the methods utilized for the synthesis of magnetic $\mathrm{Fe}_{3} \mathrm{O}_{4} / \mathrm{LDHs}$ nanocomposites and their key applications in the classical area of photo catalysis and environmental remediation were studied [151].

\subsection{LDHs Acts as Host for Drugs}

The author's in this section present drugs as excellent materials to intercalate in $\mathrm{LDHs}$ due to negative charges species. Nalawade et al. [152] reported that the $\mathrm{LDHs}$ are excellent hosts for negatively charged species which provides better methods of drugs and genetic materials that are introduced into cells. Consequently, if it is consumed, biomolecules-LDH nano-hybrid can transfer across the mucous membrane of the intestine. However, neutral hybrid may enter the cells by moving diagonally, where negative charged cell membranes without being repulsive electrostatic interactions that could be experienced alone by guest anion species. When inside the cell, the LDHs are broken down by lysosomes the resulting intercalate anion is released [152].

Biomolecules are stable in $\mathrm{LDHs}$ lattice. If required, de-intercalated by ion-exchange method with atmospheric $\mathrm{CO}_{2}$ or other anions. These exceptional characteristics will permit $\mathrm{LDH}$ s to be utilized as new drug or gene carriers if transmission is effective of bio hybrids to cells are proved. Hence, to evaluate the transfer efficiency, isotope-labeled [ $\left.{ }^{32} \mathrm{P}\right]$ ATP-LDHs hybrid was synthesized by ion exchange method and application of such hybrids by eukaryot- 
ic cells was examined for incubation time taken. Exogenously introduced ATP-LDHs hybrid enters into HL-60 cells efficiently in shorter duration of time. However, transfer effectiveness was found to be greater up to 25 -fold in $2 \mathrm{~h} \mathrm{du}$ ration of incubation, for ATP only. However, after $4 \mathrm{~h}$ of incubation, the uptake level of hybrids becomes lesser to 12 -fold. In comparison, the hybridization between ATP and LDHs it neutralizes surface charge of anionic phosphate groups in ATP, which is attributed to the cationic charge of LDHs, which results into favorable endocytosis of cells, and finally results into better transmission efficiency $[152,153]$.

Adding LDHs to a solution of desired drugs in water at room temperature results in intercalation of these molecules in LDHs. LDHs swells up to $20 \AA$ and can occupy the size of guest molecules. LDHs have excellent property of possessing antacid and antipepsin properties. Branded antacids products (TALCIDTM and ALTACITETM) contain LDH $\mathrm{Mg}_{6} \mathrm{Al}_{2}(\mathrm{OH})_{16} \mathrm{CO}_{3}$. Drugs such as Diclofenac (DIC), Ibuprofen, Naproxen, Gemfibrozil, 2Propylpentonoic acids, 4-Biphenylacetic acid, Tolfenamic acid, indomethacin, ketoprofen, tiaprofenic acid and flurbiprofen can be intercalated into LDHs [154]. Numerous cardiovascular, anti-inflammatory agents such as carboxylic acids or carboxylic acid derivatives, can be intercalated in LDHs by ion exchange method. However, intercalating into LDHs modifies Diclofenac (DIC) discharge, the interlayer region of this matrix is considered as micro vessel, in which the drug is stored and released by deintercalation method due to the ions present in small intestine [154]. The release of Diclofenac (DIC) usually depends on diffusion through particle size and not on concentration of drug. In vitro studies it shows that the drug is free by a de-intercalation procedure due to interchange of drug with ions present in dissolution medium [154]. Hence, it is observed that the drug is released from $\mathrm{LDHs}$ at $\mathrm{pH}$ 7.5. Hence, the drug is discharged from LDHs DIC is much slower than that from mixing, which is completed in 9 hours. Kinetic analysis results have observed that there is diffusion through particle in controlling drug discharged. Therefore, it is very important that the reversible intercalation of wide variety of active cardiovascular and antiinflammatory agents into LDHs that can result into new tunable drug delivery system [153]. Umberto et al. [154] (Table 5) reported that in order to examine the catalytic aptitude of $\mathrm{MgAl}$ hydrotalcites to intercalate the L-DOPA (L-3,4dihydroxyphenylalanine) that is structurally identical to amino acids which are used as drug in the Parkinson's disease. Umberto et al. [154] reported that at $\mathrm{pH} 9$ intercalation is accomplished, with hydrazine as an antioxidant. Table 4 reports the interlayer distance of intercalated compounds with amino acids bearing two carboxylic groups as glutamic (Glu) and aspartic acid (Asp) and composition of LDHs.

\subsection{LDHs as Guest Species for Antimicrobial and Antioxidant Activity}

However, the intercalation of the biologically active class into hydrotalcites that exhibits antimicrobial activity for benzoate (Bz), 2,4dichlorobenzoate (BzDC) and para- and orthohydroxybenzoate (p-BzOH, o- $\mathrm{BzOH})$ [154]. The composition of the materials is presented in Table 5 [155] directs that the benzoate, and benzoate derivatives of anions easily replaces the nitrate counter-anions finally, whereas the Fer and the Asc exchange for 53\% and 31\% to nitrate or chloride anions.

\subsection{LDHs Composite Materials}

Usually, Fe Magnetic LDHs are prepared by co-precipitation, hydrothermal, and solvothermal methods $[156,157]$. The hybrid materials of $\mathrm{LDHs}$ nanocomposite and $\mathrm{Fe}_{3} \mathrm{O}_{4}$ MNPs is highly recommended for environmental pollution control. There are few published articles studied on the synthesis of $\mathrm{Fe}_{3} \mathrm{O}_{4} / \mathrm{LDH}$ nanocomposites and for their photocatalytic applications [157] (see Table 6). The magnetic separation of $\mathrm{Fe}_{3} \mathrm{O}_{4} / \mathrm{LDHs}$ materials have been exam-

Table 5. Composition and basal spacing $(d)$ of the indicated intercalation compounds dried at $75 \%$ of relative humidity [155].

\begin{tabular}{lccc}
\hline & Acronyms & Composition & $d(\AA)$ \\
\hline Antimicrobial & Zn-Al-Bz & {$[\mathrm{ZnAl}] 0.35 \mathrm{Bz0} .35 .1 \mathrm{H}_{2} \mathrm{O}$} & 15.5 \\
& Zn-Al-O-BzOH & {$[\mathrm{ZnAl}] 0.350-\mathrm{BzOH} 0.27\left(\mathrm{NO}_{3}\right) 0.08 .1 \mathrm{H}_{2} \mathrm{O}$} & 15.5 \\
& Zn-Al-P-BzOH & {$[\mathrm{ZnAl}] 0.32 \mathrm{p}-\mathrm{BzOH} 0.33\left(\mathrm{NO}_{3}\right) 0.02 .1 \mathrm{H}_{2} \mathrm{O}$} & 15.3 \\
& Zn-Al-BzDC & {$[\mathrm{ZnAl}] 0.32 \mathrm{BzOH} 0.32\left(\mathrm{NO}_{3}\right) 0.03 .1 \mathrm{H}_{2} \mathrm{O}$} & 16.8 \\
\hline Anti-oxidant & $\mathrm{Mg}-\mathrm{Al}-\mathrm{Fer}$ & {$[\mathrm{MgAl}] 0.36(\mathrm{Fer}) 0.19(\mathrm{NO}) 0.17 .0 .89 \mathrm{H}_{2} \mathrm{O}$} & 17.3 \\
& $\mathrm{Mg}-\mathrm{Al}-\mathrm{Asc}$ & {$[\mathrm{MgAl}] 0.36(\mathrm{Asc}) 0.11 \mathrm{Cl} 0.25 .0 .29 \mathrm{H}_{2} \mathrm{O}$} & 12.8 \\
\hline
\end{tabular}




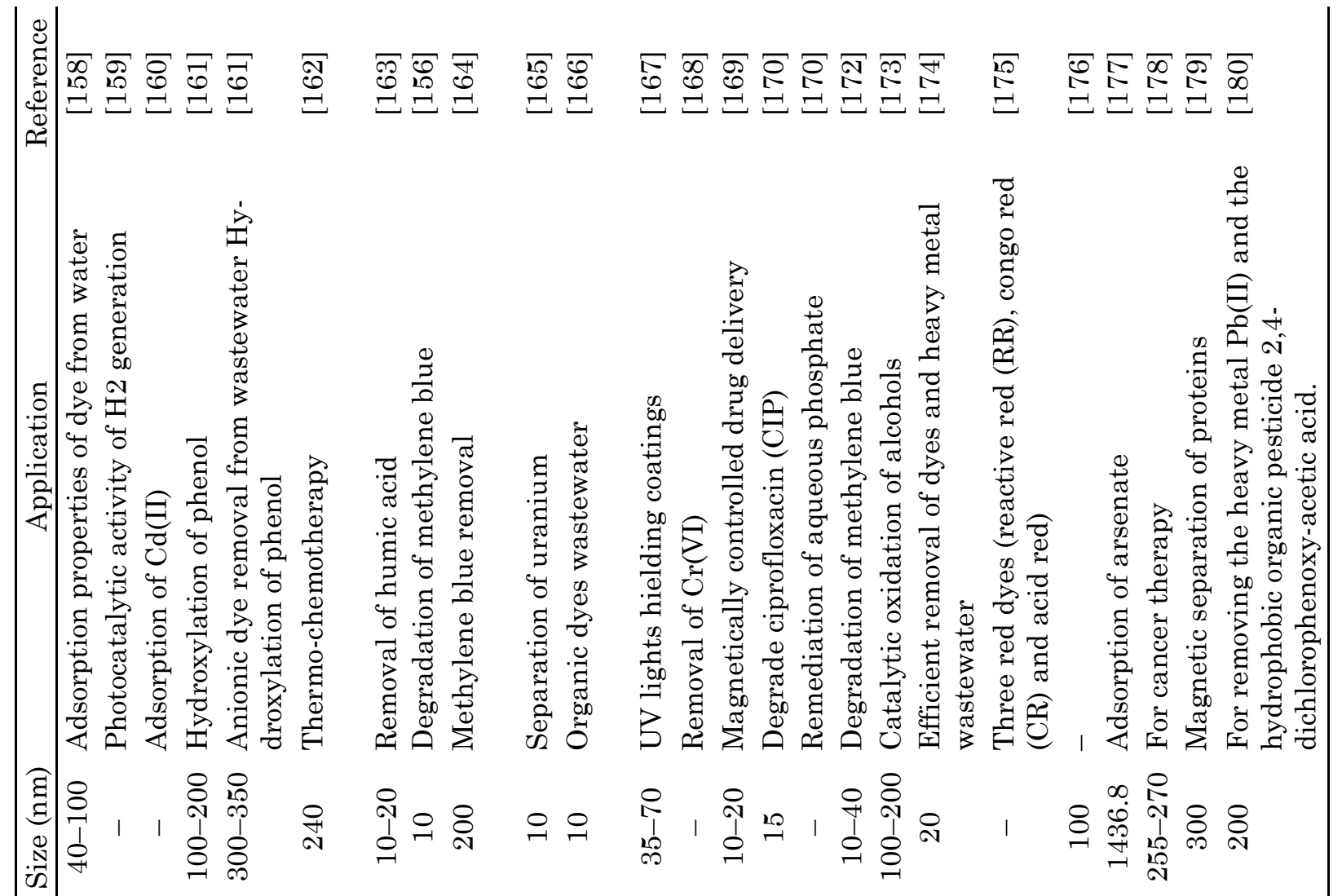


ined in aqueous solution by placing the magnet near the glass, and it displays the magnetic properties of materials [157]. As a result, separating the magnetic $\mathrm{Fe}_{3} \mathrm{O}_{4} / \mathrm{ZnCr} \mathrm{LDHs}$ nanohybrids swift variations are observed in the environmental remediation. Methylene blue (MB) is extensively utilized for photocatalytic studies as classical dye. The MB stability rises against photo catalysis when the $\mathrm{pH}$ is less, but the adjustment of $\mathrm{pH}$ to 5.4 will lead to suspension of hydrotalcite [157]. Further, Prasad et al. [150] reported that $\mathrm{MB}$ for $3 \mathrm{~h}$ at room temperature with $\mathrm{Fe}_{3} \mathrm{O}_{4} / \mathrm{ZnCr} \mathrm{LDHs}$ nanocomposite removes $\sim 95 \%$ of $\mathrm{MB}$ in aqueous solution. This result is much better when compared to $\mathrm{ZnCr} \mathrm{LDHs}$ samples, hence degrades only $58.1 \%$ under UVlight in $3 \mathrm{~h}$, this is due to $\mathrm{Fe}_{3} \mathrm{O}_{4} / \mathrm{ZnCr} \mathrm{LDHs}$ nanocomposites confirms better catalytic activity, this is ascribed due to the increased surface area and its exceptional advantage being easy separation under external magnetic fields. These results are attributed due to the modification of $\mathrm{Fe}_{3} \mathrm{O}_{4} \mathrm{NPs}$ on $\mathrm{LDHs}$ surface exhibits superior photocatalytic activity of $\mathrm{ZnCr}$ LDHs. Mardani et al. [156] reported that the $\mathrm{Cu} / \mathrm{Ni}-\mathrm{Al}$ $\mathrm{LDHs} / \mathrm{Fe}_{3} \mathrm{O}_{4}$ nanocomposite were prepared by co-precipitation method. However, magnetic $\mathrm{Fe}_{3} \mathrm{O}_{4}$ (core) were prepared by co-precipitation for $\mathrm{Fe}^{2+}$ and $\mathrm{Fe}^{3+}$ in aqueous solution. Then further nanocomposite was synthesized by coprecipitation of $\mathrm{Cu}^{2+}, \mathrm{Ni}^{2+}$, and $\mathrm{Al}^{3+}$ metal ions on the $\mathrm{Fe}_{3} \mathrm{O}_{4}$ core nanoparticles in the alkaline medium. Prasad et al. [150] reported that the results of these analyses confirms that the magnetic nanocomposite of $\mathrm{LDHs}$ and $\mathrm{Fe}_{3} \mathrm{O}_{4}$ synthesized were stable in aqueous solution via electronic interaction forces.

\subsection{Degradation of Dyes with LDHs}

LDHs are widely utilized for catalytic reactions and as catalyst supports [181] and it is further used for treatment of printing and dyeing wastewater. $\mathrm{LDH}$ s have been well known as adsorbents and photocatalysts [182,183]. Due to the dual properties as surface adsorption and interlayer adsorption of anions, $\mathrm{LDHs}$ can effectively adsorb anionic contaminants in dyeing, printing, and wastewater [184-188].

\subsection{Adsorption of Heavy Metals on LDHs}

However, it is well known that the surface water pollution and groundwater contamination are environmental problems. The main sources of environmental pollution owing to heavy metal contaminants, such as copper, lead, cadmium, chromium, arsenic, and zinc, this is ascribed due to the mining industries which are toxic at lower concentrations posing environmental challenges. Based on the nature of mining, and the level of concentrations of metal ions are huge and varies. It is already known that heavy metal ions having high toxicity and reduced biodegradability for plants and animals at greater concentrations [189,190]. Kano et al. [191] reported that the adsorption of heavy metals on LDHs intercalated with chelating agents. Perez et al. [192] reported recently that the LDHs modified with chelating agents are crucial adsorbents of heavy metals. However, Perez et al. [192] reported that the $\mathrm{ZnAl}-\mathrm{NO}_{3}$, ZnAl-EDTA, MgAl$\mathrm{NO}_{3}, \mathrm{MgAl}-\mathrm{EDTA}$, and MgAl-EDDS are active catalysts for removal of contaminants from water. Kano et al. [191] reported the adsorption capacities of $\mathrm{Cu}$ (II) or $\mathrm{Pb}$ (II) onto L1, L2, L3, and L0. The adsorption effectiveness of $\mathrm{Cu}^{2+}$ was superior compared to $\mathrm{Pb}^{2+}$ for the similar absorbent, this is ascribed due to their stability constant (EDTA- $\mathrm{Cu}$, EDDS-Cu, EDTA-Pb, EDDS-Pb. Gasser et al. [193-197] reported that due to the larger adsorption the capacity is obtained as the chelate-metal has high stability constant. Finally, it is concluded that the higher adsorption efficiency of L0 than L1 is attributed due to high specific surface area of LDHs [197-202] (see Table 1).

\subsection{Intercalating of Chelating Agents on Met-} als with $\mathrm{LDHs}$ Catalysts

Kano et al. [191] reported that remarkable results were obtained for the LDHs intercalation with chelating agents on the adsorption of metals [198]. The adsorption of $\mathrm{Cd}(\mathrm{II}), \mathrm{Cu}(\mathrm{II})$, and $\mathrm{Pb}(\mathrm{II})$ onto these $\mathrm{LDHs}$ studied in optimal conditions were obtained as reported by Liang et al. [203]. LDHs were found to adsorb Cd(II), $\mathrm{Cu}(\mathrm{II})$, and $\mathrm{Pb}$ (II) from solutions, which increases with time during the uptake was observed. It was evident from the results that the adsorption capacity of both LDHs for Cd(II), $\mathrm{Cu}(\mathrm{II})$, and $\mathrm{Pb}$ (II) improved swiftly through all the stages, and subsequently increased regularly. However, the adsorption capacity of $\mathrm{Cu}$ (II) and $\mathrm{Pb}$ (II) was observed to be greater than that of $\mathrm{Cd}(\mathrm{II})$. It was reported that the heavy metals were adsorbed by LDHs consisting of two mechanisms: chemical precipitation and chelation [203]. In the initial case, the hydroxyl anions participate with chelating agents for the precipitation of metal hydroxides at a greater $\mathrm{pH}$. In the second case, the adsorption affinity is usually evaluated by the stability constant of the analogous complex $[165,166]$. 


\section{Future Outlook and Current Opinions on LDHs Catalysts}

The key tenants on the future outlook and current opinion are highlighted as choice of metals, ions for development of reusable, reproducing of green catalysts by economic process. For the developed of value added products. Waste materials can have converted to $\mathrm{LDHs}$ catalysts, i.e. incorporating different metals to evaluate the potential use of waste materials into active LDHs green catalysts, that can be applied in different areas, such as environmental, engineering, medicine, renewable energy, and catalysis. A tunable catalyst with active metal center or sites, to be focused on for development of green process on the concept of green chemistry / green catalysts. Further future recommendations can be evaluated for fine tuning of LDHs under different parameters.

The key general areas investigated in the literature can be categorized as: The variables important to catalyst synthesis, characterization, and applications for different reactions. The commercial utilization of LDHs is very essential for the advancement of $\mathrm{LDH}$ s catalysts and requires a scalable continuous production technique to get high yield and high crystallinity. Hence, an integrated method could be employing microfluidic technology and tubular reactors needs to be explored in detail, towards the sustainable mass-scale production. Although LDHs effective work's for various organic transformations, medicine, environmental, flame retardants and many of areas of science and engineering. However, for the effective industrial applications, it is highly recommended to assess the performance of these LDHs at industrial level in order to replace the conventional catalysts.

\section{Concluding Remarks}

The aim of this review is to study new techniques developed for the preparation, characterization and applications of LDHs catalysts. LDHs acts as green catalysts that can be applied in the absence of conventional catalysts used. Green chemistry focusses on the environmental aspects of both chemical products and the technology by which they are produced. $\mathrm{LDHs}$ catalysts are green catalysts that eliminates wastes and avoids the use of toxic and or hazardous reagents and solvents in the manufacture of fine chemicals. The surface area of $\mathrm{LDH}$ is measure by $\mathrm{N}_{2}$ Physisorption which varies between $230 \mathrm{~cm}^{2} / \mathrm{g}$ and $102 \mathrm{~m}^{2} / \mathrm{g}$ depending, mainly on the active sites of LDHs cata- lysts. A typically crystalline structure of LDH is Rhombohedral and this can be verified by XRD analysis. SEM evaluates the surface morphology of LDH. Through XPS one can determine the chemical and pattern of the electronic structure of the surface of LDH. The surface area of $\mathrm{LDH}$ and adsorption-desorption process can be characterized by BET surface area. FTIR spectroscopy is vital to determine the functional group such as $\mathrm{OH}$, Carbonate, and polymer intercalated in LDH. The vibration, rotational and molecular aspects are evaluated by Raman Spectroscopy. The DTA-TGA method is applied for Measuring the variations in Mass at different temperature. The surface chemistry of metals and metal oxides are characterized by Temperature Programmed Reduction (TPR) under various thermal conditions in order to evaluate the application of reducing gas mixture that are adsorbed on the metal or metal oxide surface. However, modified LDHs catalysts can be developed for studying new applications due its tunable nature of LDHs, and excellent properties it exhibits due its active sites, memory effect, reusability, stability for longer reactions, regardless of reactions parameters applied, simple method of synthesis, economic and eco-friendly process can be developed. However, the authors evaluated that the most important and recent achievements have been reviewed on LDHs catalysts, and future recommendations have been evaluated with the ultimate goal to offer a panoramic vision of the importance and potential of this branch of material science.

\section{Funding}

Rajasekhar Pullabhotla would like to acknowledge the National Research Foundation (NRF, South Arica) for the financial support in the form of the Incentive Fund Grant (Grant No: 103691) and Research Developmental Grant for Rated Researchers (112145).

\section{Acknowledgments}

The author's acknowledge's University of Zululand, South Africa and University of Namibia, Windhoek, Namibia. To support this project. Rajasekhar Pullabhotla would like to acknowledge the National Research Foundation (NRF, South Arica) for the financial support in the form of the Incentive Fund Grant (Grant No: 103691) and Research Developmental Grant for Rated Researchers (112145). Finally, authors would like to acknowledge Mrs. Rakshana Pullabhotla for the editorial service. 


\section{References}

[1] Paulo, L., Benicio, F., Silva, R.A., Lopes, J.A., Eulalio, D., dos Santos, R.M.M., de Aquino, L.A., Vergutz, L., Novais, R.F., da Costa, L.M., Frederico G. P., Jairo. T. (2015). Layered Double Hydroxides: Nanomaterials for Applications in Agriculture. Rev. Bras. Ciênc. So lo , $\quad 39, \quad 1-13, \quad$ D O I : 10.1590/01000683rbcs20150817.

[2] Taylor, H.F.W. (1973). Crystal Structures of Some Double Hydroxide Minerals. Mineral. Mag . , $\quad 39, \quad 377-389$. D O I : 10.1180/minmag.1973.039.304.01.

[3] Ren, L., He, J., Evans, D.G., Duan, X., Ma, R. (2001). Some Factors Affecting the Immobilization of Penicillin G Acylase on Calcined Layered Double Hydroxides. J. Mol. Catal. B: Enzymatic, 16, 65-71. DOI: 10.1016/S13811177(01)00044-3.

[4] Albertazzi, S., Busca, G., Finocchio, E., Glckler, R., Vaccari, A. (2004). New $\mathrm{Pd} / \mathrm{Pt}$ on $\mathrm{Mg} / \mathrm{Al}$ Basic Mixed Oxides for the Hydrogenation and Hydrogenolysis of Naphthalene. J. Catal., 223, $372-381$. DO I : 10.1016/j.jcat.2004.01.024.

[5] Fan, G., Li, F., David, G.E, Xue, D. (2014). Catalytic applications of layered double hydroxides: recent advances and perspectives. Chem. Soc. Rev., 43, 7040-7066. DOI: 10.1039/C4CS00160E.

[6] Kirm, I., Medina, F., Rodrıguez, X., Cesteros, Y., Salagre, P., Sueiras, J. (2004). Epoxidation of Styrene with Hydrogen Peroxide Using Hydrotalcites as Heterogeneous Catalysts. Appl. Catal. A, 272, 175-185. DOI: 10.1016/j.apcata.2004.05.039.

[7] Costantino, U., Curini, M., Montanari, F., Nocchetti, M., Rosati, O. (2003). Hydrotalcitelike Compounds as Catalysts in Liquid Phase Organic Synthesis: I. Knoevenagel Condensation Promoted by $\left.\mathrm{Ni}_{0.73} \mathrm{Al}_{0.27}(\mathrm{OH})_{2}\right]\left(\mathrm{CO}_{3}\right)_{0.135}$. J. Mol. Catal. A: Chem., 195, 245-252. DOI: 10.1016/S13811169(02)00580-0.

[8] Choudary, B.M., Madhi, S., Chowdari, N.S., Kantam, M.L., Sreedhar, B. (2002). Layered Double Hydroxide Supported Nanopalladium Catalyst for Heck-, Suzuki-, Sonogashira-, and Stille-Type Coupling Reactions of Chloroarenes. J. Am. Chem. Soc., 124, 1412714136. DOI: $10.1021 / \mathrm{ja} 026975 \mathrm{w}$.

[9] Rives, V., Prieto, O., Dubey, A., Kannan, S. (2003). Synergistic Effect in the Hydroxylation of Phenol over CoNiAl Ternary Hydrotalcites. J. Catal., 220, 161-171. DOI: 10.1016/S0021-9517(03)00245-8.
[10] Bish, D.L. (1980). Anion Exchange in Takovite: Applications to Other Hydroxide Minerals. Bull. Mineral, 103, 170-175. DOI: 10.3406/bulmi.1980.7392.

[11] Comelli, N.A., Ruiz M.L., Aparicio, M.S.L., Merino N.A., Cecilia, J.A., Rodríguez Castellón, E., Lick, I.D., Ponzi M.I. (2018). Influence of the synthetic conditions on the composition, morphology of $\mathrm{CuMgAl}$ hydrotalcites and their use as catalytic precursor in Diesel soot combustion reactions. Applied Clay Science, 157, 148-157. D O I : 10.1016/j.clay.2018.02.039.

[12] Corma, A., Palomares, A.E., Rey, F., Marquez, F. (1997). Simultaneous Catalytic Removal of SOx and NOx with Hydrotalcite Derived Mixed Oxides Containing Copper, and Their Possibilities to be used in FCC Units. J. Catal., 170, 140-149. DOI: 10.1006/jcat.1997.1750.

[13] Palomares, A.E., Lopez-Nieto, J.M., Lazaro, F.J., Lopez, A., Corma, A. (1999). Reactivity in the Removal of $\mathrm{SO}_{2}$ and $\mathrm{NOx}$ on $\mathrm{Co} / \mathrm{Mg} / \mathrm{Al}$ Mixed Oxides Derived from Hydrotalcites. Appl. Catal. B Environ., 20, 257-266. DOI: 10.1016/S0926-3373(98)00121-0.

[14] Huang, X., Yang, X., Li, G., I. Ezeh, C., Sun, C., Snape, C. (2019). Hybrid Two-step Preparation of Nanosized MgAl Layered Double Hydroxides for $\mathrm{CO}_{2}$ Adsorption. Infotech, C h a p t e r , $10, \quad 1-21$. D O I : 10.5772/infotechopen.8660.

[15] Aminu, K., Nooraini, A., Mohd, H., Sharida, F.H., Samer, A. (2014). Toxicity and Metabolism of Layered Double Hydroxide Intercalated with Levodopa in a Parkinson's Disease Model. Int. J. Mol. Sci., 15, 5916-5927. DOI: 10.3390/ijms 15045916 .

[16] Kim, H.J., Lee, G.J., Choi, A.J., Kim, T.H., Kim, T.I., Oh, J.M. (2018). Layered double hydroxide nanomaterials encapsulating angelica gigas nakai extract for potential anticancer nanomedicine. Front. Pharmacol., 9, 723. DOI: 10.3389/fphar.2018.00723.

[17] Qin-Zheng, Y., Ying-Yue, C., Hua-Zhang, Z. (2013). Preparation and antibacterial activity of lysozyme and layered double hydroxide nanocomposites. Water Res. 1; 47(17), 6712-8. DOI: 10.1016/j.watres.2013.09.002.

[18] Lagnamayee, M., Dhananjaya, P., Kulamani, P., Javaid, Z.S. (2017). Enhanced Photocatalytic Activity of a Molybdate-Intercalated Iron-Based Layered Double Hydroxide. Eur. J. Inorg. Chem., 2017, 723-733. DOI: 10.1002/ejic.201601191. 
[19] Kentaro, T., Hideo, T., Kentaro, O., Takashi, S., Tetsuya, S., Tsunehiro, T. (2014). Photoactivation of Molecular Oxygen by an Iron (III) Porphyrin with a Magnesium Aluminum Layered Double Hydroxide for the Aerobic Epoxidation of Cyclohexene. ChemCatChem, 6, 2276-2281. DOI: 10.1002/cctc.201402131.

[20] Shirley, N., Kelly, A.D.F.C., Geani, M.U., Matilte, H., Vanessa, P., Claude, F., Fernando, W. (2014). Anionic Iron(III) Porphyrin Immobilized on/into Exfoliated Macroporous Layered Double Hydroxides as Catalyst for Oxidation Reactions. J. Braz. Chem. Soc., 25 (12), DOI: 10.5935/0103-5053.20140241.

[21] Xianggui, K., Jingwen, Z., Jingbin, H., Danyao, Z., Min, W., Xue, D. (2011). Fabrication of Naphthol Green B/Layered Double Hydroxide Nanosheets Ultrathin Film and Its Application in Electrocatalysis. Electrochim. Acta., $56, \quad 1123-1129$. D O I : 10.1016/j.electacta.2010.10.081.

[22] Hessamaddin, S., Alireza, K., Shahin, G., Mir R.M., Yasin, O. (2021). A review of status and prospects Layer double hydroxides (LDHs)based electrochemical and optical sensing assessments for quantification and identification of heavy metals in water and environment samples. Trends in Environmental Analytical Chemistry, 31, e00139. DOI: 10.1016/j.teac.2021.e00139.

[23] Kiyoharu, T., Kohei, I., Takashi, K., Akira, M., Mikio, H. (2015). Development of Alkaline Fuel Cells Using Hydroxide-Ion Conductive Layered Double Hydroxides. ECS Transactions, 69, 17, 385-390. DOI: 10.1149/06917.0385ecst.

[24] Yu, F., Zhou, H., Huang, Y., Jingying, S., Fan, Q., Jiming, B., William, A.G., Shuo, C., Zhifeng, R. (2018). High-performance bifunctional porous non-noble metal phosphide catalyst for overall water splitting. Nature Communications, 9(1), 2551. DOI: 10.1038/s414167-01804746-z

[25] Xiao, X., Huang, D., Fu, Y. Ming, W., Xingxing, J., Xiaowei, L., Lin, G., Shuanghuang, L., Mengkui, W., Chuan, Z., Yan, S. (2018). Engineering NiS/Ni2P heterostrucures for efficient electrocatalytic water splitting. ACS Applied Materials \& Interfaces, $10 \quad(5), \quad 4689-4696$. D O I : 10.1021/acsami.7b16430.

[26] Song, Y., Ji, K., Duan, H., Shao, M. (2021). Hydrogen production coupled with water and organic oxidation based on layered double hydroxides. Exploration, 1, 20210050., 1-12. DOI: 10.1002/EXP.20210050.
[27] Shalini, K., Nur Hawa, N.A., Yusran, S. (2020). Advances in Layered Double Hydroxide/Carbon Nanocomposites Containing $\mathrm{Ni}^{2+}$ and $\mathrm{Co}^{2+/ 3+}$ for Supercapacitors. Frontiers in Materials, 7, 147, 1-22. DOI: 10.3389/fmats.2020.00147.

[28] Zhang, J., Wang, X., Zhan, S., Li, H., Ma, C., Qiu, Z. (2021). Synthesis of Mg/Al-LDH nanoflakes decorated magnetic mesoporous MCM-41 and its application in humic acid adsorption. Microchemical Journal, 162, 105839. DOI: 10.1016/j.microc.2020.105839.

[29] Fan, X., Cao, Q., Meng, F., Song, B., Bai, Z., Zhao, Y., Chen, D., Zhou, Y., Song, M. (2021). A Fenton-like system of biochar loading FeAl layered double hydroxides (FeAl-LDH@BC) / $\mathrm{H}_{2} \mathrm{O}_{2}$ for phenol removal. Chemosphere, 266 $128992, \quad 1-9 . \quad$ D O I : 10.1016/j.chemosphere.2020.128992.

[30] Xin, H., Xinhong, Q., Chenyan, H., Yawen, L. (2018). Treatment of heavy metal ions in wastewater using layered double hydroxides: A review. Journal of Dispersion Science and Technology, 39(6), 792-801, DOI: 10.1080/01932691.2017.1392318.

[31] Xue, B., Hui, Z., Liguang, D. (2014). Review Layered Double Hydroxide-Based Nanocarriers for Drug Delivery. Pharmaceutics, 6, 298332. DOI: 10.3390/pharmaceutics6020298.

[32] Wen, J., Yang, K., Huang, J., Sun, S. (2021). Recent advances in LDH-based nanosystems for cancer therapy. Materials and Design, $198, \quad 109298, \quad$ D O I : 10.1016/j.matdes.2020.109298.

[33] Feng, X., Jiao, Q., Chen, W., Dang, Y., Dai, Z., Suib, S.L., Zang, J., Zhao, Y., Li, H., Feng, C. (2021). Cactus-like $\mathrm{NiCo}_{2} \mathrm{~S}_{4} @ \mathrm{NiFe} \mathrm{LDH}$ hollow spheres as an effective oxygen bifunctional electrocatalyst in alkaline solution. Applied Catalysis B: Environmental, 286, 119869. DOI: $10.1016 /$ j.apcatb.2020.119869.

[34] Bukhtiyarova, M.V. (2019). A review on effect of synthesis conditions on the formation of layered double hydroxides. Journal of Solid State Chemistry, 269, 494-506. DOI: 10.1016/j.jssc.2018.10.018.

[35] Zubair, M., Daud, M., McKay, G., Shehzad, F., Al-Harthi, M.A. (2017). Recent progress in layered double hydroxides (LDH)-containing hybrids as adsorbents for water remediation. Appl. Clay Sci., 143, 279-292. DOI: 10.10116/j.clay.2017.04.002.

[36] Zhao, M.Q., Zhang, Q., Huang, J.Q., Wei, F. (2012). Hierarchical nanocomposites derived from nanocarbons and layered double hydroxides - properties, synthesis, and applications. Adv. Funct. Mater., 22, 675-694. DOI: 10.1002/adfm.201102222. 
[37] Cao, Y., Li, G., Li, X. (2016). Graphene/layered double hydroxide nanocomposite: properties, synthesis, and applications. Chem. Eng. J., 292, 207-223. DOI: 10.1016/j.cej.2016.01.114.

[38] Mishra, G., Dash, B., Pandey, S. (2018). Layered double hydroxides: a brief review from fundamentals to application as evolving biomaterials. Appl. Clay Sci., 153, 172-186, DOI: 10.1016/j.clay.2017.12.021.

[39] Tichit, D., Layrac, G., Gérardin, C. (2019). Synthesis of layered double hydroxides through continuous flow processes: a review. Chem. Eng. J., 369, 302-332. DOI: 10.1016/j.cej.2019.03.057

[40] Forano, C., Hibino, T., Leroux, F., TaviotGueho, C. (2006). Layered double hydroxides. In Bergaya, F., Theng, B.K.G., Lagaly, G. (Eds.) Handbook of Clay Science vol. 1. Amsterdam: Elsevier Science Bv.

[41] Rives, V. (2001). Layered Double Hydroxides: Present and Future. New York: Nova Science Publishers, Inc.

[42] Ian, T.S. (2015). Layered Double Hydroxides (LDHs): Synthesis, Characterization and Applications. Series: Materials Science and Technologies.

[43] Costantino, U., Marmottini, F., Nocchetti, M., Vivani, R. (1998). New synthetic routes to hydrotalcite-like compounds - characterisation and properties of the obtained materials. Eur. J. Inorg. Chem., 1998(10), 1439-1446. DOI:

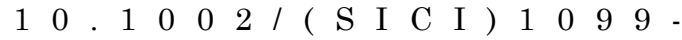
0682(199810)1998:103.0.CO;2-1.

[44] Conterosito, E., Beek, W.V., Palin, L., Croce, G., Perioli, L., Viterbo, D., Gatti, G., Milanesio, M. (2013). Development of a fast and clean intercalation method for organic molecules into layered double hydroxides. Crystal growth \& Design, 13(3), 1162-1169. DOI: $10.1021 / \mathrm{cg} 301505 \mathrm{e}$.

[45] Jubri, Z., Hussein, M.Z., Yahaya, A., Zainal, Z. (2012). The effect of microwave-assisted synthesis on the physico-chemical properties of pamoate-intercalated layered double hydroxide. Nanosci. Methods, 1, 152-163. DOI: 10.1080/17458080.2011.630036.

[46] Benito, P., Guinea. I., Herrero. M., Labajos, F.M., Rives, V. (2007). Incidence of microwave hydrothermal treatments on the crystallinity properties of hydrotalcite-like compounds. Zeitschrift fur Anorg. und Allg. Chemie., 633, 1815-1819. DOI: 10.1002/ZAAC.200700178.

[47] Bergadà, O., Vicente, I., Salagre, P., Cesteros, Y., Medina, F., Sueiras, J.E. (2007). Microwave effect during aging on the porosity and basic properties of hydrotalcites. Microporous Mesoporous Mater., 101, 363-373. DOI: 10.1016/j.micromeso.2006.11.033.
[48] Abito, G., Bonasera, A., Prestopino, G., Orsini, A., Mattoccia, A., Martinelli, E., Pignataro, B., Medaglia, P.G. (2019). Layered Double Hydroxides: A Toolbox for Chemistry and Biology. Crystals, 9, 361. DOI: 10.3390/cryst9070361.

[49] Zhao, M.Q., Zhang, Q., Huang, J.Q., Wei, F. (2012). Hierarchical nanocomposites derived from nanocarbons and layered double hydroxides-properties, synthesis, and applications. Adv. Funct. Mater., 22, 675-694. DOI: 10.1002/adfm.201102222.

[50] Zhen, L., Zhaoling, M., Yanyong, W., Ru, C., Zhenjun, W., Shuangyin. W. (2018). LDHs derived nanoparticle-stacked metal nitride as interlayer for long-life lithium sulfur batteries. Science Bulletin, 63, 3, 169-175. DOI: 10.1016/j.scib.2017.12.018.

[51] Zexuan, Z., Peilong, L., Xin, Z., Cun, H., Yuwen, L., Bin, Y., Ning, Z., Chao, L., Jiangfeng, S., Mingcan, L. (2021). Recent Advances in Layered-Double-Hydroxides Based Noble Metal Nanoparticles Efficient Electrocatalysts. Nanomaterials, 11, 2644, 1-17. DOI: $10.3390 /$ nano11102644.

[52] Newman, S.P., Jones, W. (1998). Synthesis, characterization and applications of layered double hydroxides containing organic guests. New J. Chem., 22, 105-115. DOI: 10.1039/A708319J.

[53] Leroux, F., Taviot-Guého, C. (2005). Fine tuning between organic and inorganic host structure: New trends in layered double hydroxide hybrid assemblies. J. Mater. Chem., 15, 3628-3642. DOI: 10.1039/B505014F.

[54] Rives, V., Ulibarri, M.A. (1999). Layered double hydroxides $(\mathrm{LDH})$ intercalated with metal coordination compounds and oxometalates Coord. Chem. Rev., 181, 61-120. DOI: 10.1016/S0010-8545(98)00216-1.

[55] Omwoma, S., Chen, W., Tsunashima, R., Song, Y.F. (2014). Recent advances on polyoxometalates intercalated layered double hydroxides: from synthetic approaches to functional material applications. Coord. Chem. Rev., 258-259, 58-71. DOI: 10.1016/j.ccr.2013.08.039.

[56] Bouali, A.C., Serdechnova, M., Blawert, C., Tedim, J., Ferreira, M.G.S., Zheludkevich, M.L. (2020). Layered double hydroxides $(\mathrm{LDHs})$ as functional materials for the corrosion protection of aluminum alloys: A review. Applied Materials Today, 21, 100857, 1-42. DOI: $10.1016 /$ j.apmt.2020.100857.

[57] Iqbal, M.A., Sun, L., Barrett, A.T., Fedel, M. (2020). Review Layered Double Hydroxide Protective Films Developed on Aluminum and Aluminum Alloys: Synthetic Methods and Anti-Corrosion Mechanisms. Coatings, 10, 428. DOI: 10.3390/coatings 10040428 . 
[58] Richetts, M. (2017). Characteristics, Preparation Routes and Metallurgical Applications of LDHs: An Overview. J. Material. Sci. Eng., 6(6), 1-11. DOI: 10.4172/2169-0022.1000397.

[59] Ding, X., Wu, L., Chen, J., Zhang, G., Xie, Z., Sun, D., Jiang, B., Atrens, A., Pan, F. (2020). Enhanced protective nanoparticle-modified MgAl-LDHs coatings on titanium alloy. Surface and Coatings Technology, 404, 126449. DOI: 10.1016/j.surfcoat.2020.126449.

[60] Liu, T., Zhou, H., Zhong, G., Yan, X., Su, X., Lin, Z. (2021). Synthesis of NiFeAl LDHs from electroplating sludge and Their excellent supercapacitor performance. Journal of Hazardous Materials, 404, 124113. DOI: 10.1016/j.jhazmat.2020.124113.

[61] Sònia, A., Francesc, M., Didier, T., Javier, P. R., Johan, C.G., Jesús, E.S., Pilar, S., Yolanda, C. (2005). Aldol condensations over reconstructed Mg-Al hydrotalcites: structureactivity relationships related to the rehydration method. Chemistry 1(2), 728-739. DOI: 10.1002/chem.200400409.

[62] Biplab, R., Anupam, S.R., Asit, B.P., Manirul, I.S.K, Asoke, P.C. (2016). Nano-structured Magnesium Oxide as Efficient Recyclable Catalyst for Knoevenagel and Claisen-Schmidt Condensation Reactions. Chemistry Select. 1, 15, 4778-47784, DOI: 10.1002/slct.201600380.

[63] Chen, D., Li, Y., Zhang, J., Zhou, J., Guo, Y., Liu, H. (2012). Magnetic $\mathrm{Fe}_{3} \mathrm{O}_{4} / \mathrm{ZnCr}$-layered double hydroxide composite with enhanced adsorption and photo catalytic activity. Chem. Eng. J., 185(186), 120-126. DOI: 10.1016/j.cej.2012.01.059.

[64] Francisco, T., Castillo-Rodríguez, J.C., Tzompantzi-Flores, C., Raúl Pérez, H., Gómez, R., Santolalla-Vargas, C.E., Che-Galicia, G., Ramos-Ramírez, E. (2021). Addition of $\mathrm{SnO}_{2}$ over an oxygen deficient zirconium oxide (ZrxOy) and its catalytic evaluation for the photodegradation of phenol in water. Catalysis Today, DOI : 10.1016/j.cattod.2021.07.027.

[65] Claudia, A., Reyna, N., Barrera-Diaz, C., Martínez-Miranda, V., Julia, P., Jaime, S.V. (2013). Photocatalytically enhanced Cr(VI) removal by mixed oxides derived from $\mathrm{MeAl}$ (Me: $\mathrm{Mg}$ and/or $\mathrm{Zn}$ ) layered double hydroxides. Applied Catalysis B: Environmental, 140 ( 141 ) , $546-551$. D O I : 10.1016/j.apcatb.2013.04.053.

[66] Sheldon, R.A. (2001). van Bekkum H. (Eds.), , Ch. 7. Fine Chemicals Through Heterogeneous Catalysis. Wiley-VCH, Weinheim.

[67] Bukhtiyarova, M.V. (2019). A review on effect of synthesis conditions on the formation of layered double hydroxides. J. Solid State Chem., 269, 494-506. D O : 10.1016/j.jssc.2018.10.018.
[68] Qiong, Z., Huan, L. (2014). Mg/Al layered double hydroxides prepared by microwaveassisted co-precipitation method for the removal of bromate. Huan Jing Ke Xue, 35, 4, 1566-1575.

[69] Hyung Mi, L., Mi, R.K., Sang, C.L., Seung Ho, L., Kwang, J.K. (2005). Effect of Microwave Heating on the Synthesis of Layered Double Hydroxide. Material Science Forum. 492-493, 743-748.

[70] Choudary, B.M., Kantam, M.L., Rahman, A., Reddy, C.V., Rao, K.K. (2001). The First Example of Activation of Molecular Oxygen by Nickel in Ni-Al Hydrotalcite: A Novel Protocol for the Selective Oxidation of Alcohols. Angew. Chem. Int. Ed., 40, 763-766. DOI: 10.1002/1521-3773(20010216)40:43.0.CO;2-T

[71] Choudary, B.M., Kantam, M.L., Rahman, A., Reddy, C.R.V. (2003). Selective reduction of aldehydes to alcohols by calcined Ni-Al hydrotalcite. Journal of Molecular Catalysis A: Chemical, 206, 145-151. DOI: 10.1016/S13811169(03)00413-8.

[72] Kantan, M.L., Kavita, B., Rahman, A., Sateesh, M. (1998). Mg-AlCO ${ }_{3}$ Catalysed Ring Opening of Oxiranes with TMSN3. Indian Journal of Chemistry Sect. B. (37), 1039-1041. http://nopr.niscair.res.in/handle/123456789/5 6930.

[73] Kim, T.H., Lee, G.J., Kang, J.H., Kim, H.J., Kim, T.I., Oh, J.M. (2014). Anticancer DrugIncorporated Layered Double Hydroxide Nanohybrids and Their Enhanced Anticancer Therapeutic Efficacy in Combination Cancer Treatment. BioMed Research International. 193401, 1-11. DOI: 10.1155/2014/193401.

[74] Hashim, N., Hussein, MZ., Isa, I.M., Kamari, A., Mohamed, A., Azmi, M., Adila, M.J., Haf sah, T. (2014). Synthesis and controlled release of cloprop herbicides from cloprop layered double hydroxide and cloprop zinc layered hydroxide nanocomposites. Open Journal of Inorganic Chemistry, 4(1), 1-9. DOI: 10.4236/ojic.2014.41001.

[75] Hai Nguyen, T., Chu-Ching, L., Huang-Ping, C. (2018). Amino acids-intercalated $\mathrm{Mg} / \mathrm{Al}$ layered double hydroxides as dual-electronic adsorbent for effective removal of cationic and oxyanionic metal ions. Separation and Purification Technology. 192, 36-45. DOI: 10.1016/j.seppur.2017.09.060.

[76] Hirokazu, N., Natsuko, W., Mitsutomo, T. (2004). Intercalation of amino acids and peptides into $\mathrm{Mg}-\mathrm{Al}$ layered double hydroxide by reconstruction method. International Journal of Pharmaceutics. 269(2), 469-478. DOI: 10.1016/j.ijpharm.2003.09.043. 
[77] Yang, Q.Z., Chang, Y.Y., Zhao, H.Z. (2013). Preparation and Antibacterial Activity of Lysozyme and Layered Double Hydroxide Nanocomposites. Water. Res., 47, 6712-6718. DOI: 10.1016/j.watres.2013.09.002.

[78] Rahman, A., Al-Dayeb, S.S. (2011). Structure characterization and application of $\mathrm{Ni}$ hydrotalcite as solid bas catalysts for organic transformations. J. Chil. Chem. Soc., 56(1), 598-600. DOI: $10.4067 / \mathrm{S} 0717-$ 97072011000100017.

[79] Man, P., Chang-Il, L., Young, J. S. (2009). Hybridization of the natural antibiotic, cinnamic acid, with layered double hydroxides (LDH) as green pesticide. Environmental Science and Pollution Research. 17(1), 203-209. DOI: 10.1007/s11356-009-0235-0.

[80] Collins, I.E., Marco, T., Xiaogang, Y., Jun, H., Cheng-Gong, S. (2018). Ultrasonic and Hydrothermal Mediated Synthesis Routes for Functionalized Mg-Al LDH: Comparison Study on Surface Morphology, Basic Site Strength, Cyclic Sorption Efficiency and Effectiveness. Ultrasonics Sonochemistry, 40, 341-352. DOI: 10.1016/j.ultsonch.2017.07.013.

[81] Bayu, W., Puji, K., Purbaningtias, T.E., Fatimah, I. (2015). Synthesis and Characterization of Hydrotalcite at Different Mg/Al Molar Ratios. Procedia Chemistry, 17, 21-26. DOI: 10.1016/j.proche.2015.12.115.

[82] Wu, L. (2017). Influence of reaction temperature on the controlled growth of $\mathrm{Mg}-\mathrm{Al} \mathrm{LDH}$ film. Int. J. Electrochem. Sci., 12, 6352-6364. DOI: $10.20964 / 2017.07 .74$.

[83] Zai, J.T., Liu, Y.Y., Li, X.M., Ma, Z.F., Qi, R.R., Qian, X.F. (2017). 3D hierarchical CoAl layered double hydroxides with long-term stabilities and high rate performances in supercapacitors. Nano-Micro Lett., 9, 21-29. DOI: $10.1007 / \mathrm{s} 40820-016-0121-5$.

[84] Choudary, B.M., Kantam, M.L., Reddy, C.V., Aranganathan, S., Lakshmi, P.S., Figueras, F. (2000). Mg-Al-O-t -Bu hydrotalcite: a new and efficient heterogeneous catalyst for transesterification. J. Molec. Catal. A, 159, 411416. DOI: 10.1016/S1381-1169(00)00209-0.

[85] Nishesh Gupta, K., Md, S., Kim, S., Kim, K.S. (2020). Microscopic, spectroscopic, and experimental approach towards understanding the phosphate adsorption onto $\mathrm{Zn}-\mathrm{Fe}$ layered double hydroxide. Journal of Molecular Liquids , 297, 111935 . D O I : 10.1016/j.molliq.2019.111935.

[86] Karolina, R., Matusik, J., Kuligiewicz, A., Leiviskä, T., Cempura, G. (2021). Surface chemistry and structure evaluation of $\mathrm{Mg} / \mathrm{Al}$ and $\mathrm{Mg} / \mathrm{Fe} \mathrm{LDH}$ derived from magnesite and dolomite in comparison to $\mathrm{LDH}$ obtained from chemicals. Applied Surface Science, 538, 147923. DOI: 10.1016/j.apsusc.2020.147923.
[87] Fatima, Z.M, Abderrahim, K., Mohamed, A., Noureddine, B. (2017). Zn-Al layered double hydroxides intercalated with carbonate, nitrate, chloride and sulfate ions: Synthesis, characterization and dyes removal properties. Journal of Taibah University for Science. 11, 1, 90-100. DOI: 10.1016/j.jtusci.2015.10.007.

[88] Luíz, P.F.B., Denise, E., Luciano de, M.G, Frederico, G.P., da Costa, L.M., Tronto, J. (2018). Layered Double Hydroxides as Hosting Matrices for Storage and Slow Release of Phosphate Analyzed by Stirred-Flow Method. Materials Research, 21(6), 20171004. DOI: 10.1590/1980-5373-MR-2017-1004.

[89] Giphin, G., Saravana, K.M.P. (2017). Synthesizing methods of layered double hydroxides and its use in the fabrication of dye Sensitised solar cell (DSSC): A short review. Materials Science and Engineering, 263, 032020, 1-9. DOI: 10.1088/1757-899X/263/3/032020.

[90] Chia-Hsuan, L., Hsueh-Liang, C., Weng-Sing, H., Moo-Chin, W., Horng-Huey, K. (2017). Synthesis and optical properties of $\mathrm{Mg}-\mathrm{Al}$ layered double hydroxides precursor powders. AIP Advances, 7, 12, 5005, 1-11. DOI: 10.1063/1.4990832.

[91] Molano-Mendoza, M., Donneys-Victoria, D., Marriaga-Cabrales, N., Angel Mueses, M., Li Puma, G., Machuca-Martínez, F. (2018). Synthesis of $\mathrm{Mg}-\mathrm{Al}$ layered double hydroxides by electrocoagulation. Methods X, 5, 915-923. DOI: 10.1016/j.mex.2018.07.019.

[92] Marcu, I., Urdă, A., Popescu, I., Hulea, V. (2017). Layered Double Hydroxides-Based Materials as Oxidation Catalysts. In M. Putz, \& M. Mirica (Ed.) Sustainable Nanosystems Development, Properties, and Applications. Hershey, PA: IGI Global. DOI: 10.4018/978-15225-0492-4.ch003.

[93] Carrado, K.A., Csencsits, R., Thiyagarajan, P., Seifert, S., Macha, S.M., Harwood, J.S. (2002). Crystallization and textural porosity of synthetic clay minerals. Journal of Materials Chemistry, 12, 3228-3237. DOI: 10.1039/b204180b.

[94] Said, A., Mohammed, N.B., Sadik, A., Hamid, Z., Omar, Q. (2020). Effect of Mg/Al molar ratio on the basicity of $\mathrm{Mg}-\mathrm{Al}$ mixed oxide derived from $\mathrm{Mg}$ - $\mathrm{Al}$ hydrotalcite. Mediterranean Journal of Chemistry, 10, 625-633. DOI: 10.13171/mjc10602007021464sa.

[95] Hongri, S., Haohong, D., Chunping, C., JeanCharles, B., Dermot, O.H. (2019). Bifunctional acid-base mesoporous silica@aqueous miscible organic-layered double hydroxides. $R S C$ Adv., 9, $3749-3754$. D O I : 10.1039/C9RA00188C. 
[96] Debecker, D.P., Gaigneaux, E.M., Busca, Guido. (2009). Exploring, Tuning, and Exploiting the Basicity of Hydrotalcites for Applications in Heterogeneous Catalysis. Chemistry. 15, 3920-3935. DOI: 10.1002/chem.200900060.

[97] Ibrahim, R., Lwin, Y. (2010). Adsorbents derived from $\mathrm{Mg}-\mathrm{Al}$ hydrotalcite like compounds for high temperature hydrogen storage. Journal of Applied Sciences, 10(12), 1128-1133. DOI: 10.3923/jas.2010.1128.1133.

[98] Saikia, H., Basumatary, S. (2019). MgRuAllayered Double Hydroxides (LDH): An Efficient Multifunctional Catalyst for Aldol Condensation and Transfer Hydrogenation Reactions. Current Catalysis, 4, 8. DOI: $10.2174 / 2211550108666190418125857$.

[99] Shanshan, X., Sarayute, C., Yan, S., Shaojun, X., Yi-chi, W., Sarah, H., Yibing, M., Yilai, J., Cristina, E.S., Huanhao, C., Xiaolei, F., Christopher, H. (2020). Mechanistic study of nonthermal plasma assisted $\mathrm{CO}_{2}$ hydrogenation over $\mathrm{Ru}$ supported on $\mathrm{MgAl}$ layered double hydroxide. Applied Catalysis B Environmental B, 268, 118752 , D O : 10.1016/j.apcatb.2020.118752.

[100] Ateeq, R., Al-Dayeb, S.S. (2011). Structure characterization and application of $\mathrm{Ni}$ hydrotalcite as solid bas catalysts for organic transformations. J. Chil. Chem. Soc., 56(1), 598-600.

[101] Harding, H., Peters, A.W., Nee, J.R.D. (2001). New developments in FCC catalyst technology. Appl. Catal. A, 221, 389. DOI: 10.1016/S0926-860X(01)00814-6.

[102] Xavier, K.O., Sreekala, R., Rashid, K.K.A., Yusuff, K.K.M., Sen, B. (1999). Doping effects of cerium oxide on $\mathrm{Ni} / \mathrm{Al} 2 \mathrm{O} 3$ catalysts for methanation. Catal. Today, 49, 17-21. DOI: 10.1016/s0920-5861(98)00403-9.

[103] Santos, R.M.M.D., Gonçalves, R.G.L., Constantino, V.R.L., Santilli, C.V., Borges, P.D., Tronto, J., Pinto, F.G. (2017). Adsorption of Acid Yellow 42 dye on calcined layered double hydroxide: effect of time, concentration, $\mathrm{pH}$ and temperature. Appl. Clay Sci., 140, 132139. DOI: 10.1016/j.clay.2017.02.005.

[104] Octavian D. Pavel, Didier T, Ioan-Cezar M (2012). Acido-basic and catalytic properties of transition-metal containing $\mathrm{Mg}-\mathrm{Al}$ hydrotalcites and their corresponding mixed oxides. Applied Clay Science, 61, 52-58. DOI: 10.1016/j.clay.2012.03.006.

[105] Fahimeh, A, Mokhtari, J., Tahoori, F. (2019). Layered double hydroxides (LDHs): As efficient heterogeneous catalyst for the cyanosilylation of aromatic aldehydes. Phosphorus, Sulfur, and Silicon and the Related Elements, $194 \quad(1-2), \quad 76-82$. D O I : 10.1080/10426507.2018.1492920.
[106] Rahman, A. (2013). Structure characterization and application of Ni hydrotalcite as environmentally friendly catalysts for reductive amination of benzaldehyde. International Journal of Engineering Sciences \& Emerging Technologies, 56(1), 598-600.

[107] Rahman, A., Pelletier, A., Mupa, M., Mahamadi, C., Musekiwa, C. (2016). Environment-Friendly Reduction of Aromatics to Alicyclic Compounds at Room Temperature Using Superactive Calcined Ni-Al Hydrotalcite Catalysts. American Journal of Applied Chemistry, 4(1), 18-23. DOI: 10.11648/j.ajac.20160401.14.

[108] Choudary, B.M., Someshwar, T., Reddy, C.V., Kantam, M.L., Ratnam K.J., Sivaji, L.V. (2003). The first example of bromination of aromatic compounds with unprecedented atom economy using molecular bromine. Applied Catalysis A: General, 251, 397-409. DOI: 10.1016/S0926-860X(03)00379-X.

[109] Palomares, A.E., Franch, C., Corma, A. (2011). A study of different supports for the catalytic reduction of nitrates from natural water with a continuous reactor. Catal. Today, $172 \quad$ (1), $90-94 . \quad \mathrm{D} \quad \mathrm{O} \quad \mathrm{I}$ : 10.1016/j.cattod.2011.05.015.

[110] Adamski, A., Gil, B., Sojka, S. (2008). Role of vanadium sites in $\mathrm{NO}$ and $\mathrm{O}_{2}$ adsorption processes over $\mathrm{VOx} / \mathrm{CeO}_{2}-\mathrm{ZrO}_{2}$ catalysts EPR and IR studies. Catal. Today, 137, 292-299. DOI: 10.1016/j.cattod.2008.02.002.

[111] Olena, D., Eleonora, B., Alexey, K. (2018). Propylene oxide polymerization in the presence of layered double hydroxides. Chem. $\mathrm{Di}$ dact. Ecol. Metrol. 23(1-2), 137-142. DOI: 10.1515/cdem-2018-0009.

[112] Laycock, D.E., Collacott, R.J., Skelton, D.A., Tchir, M.F. (1991). Stereospecific polymerization of propylene oxide on thermally activated synthetic hydrotalcite. Journal of Catalysis, 2, 354-358. DOI: 10.1016/00219517(91)90119-O.

[113] Tengfei, L., Lin, J.W.Z., Haralampos, N.M., Yu-Fei, S. (2018). Robust and Environmentally Benign Solid Acid Intercalation Catalysts for the Aminolysis of Epoxides. ChemCatChem, 10, 20, 4699-4706. DOI: 10.1002/cctc.201801119.

[114] Weijie, Z., Pingping, J., Ying, W., Jian, Z., Pingbo, Z. (2016). Manganese(III) Tetraphenylporphyrin Encapsulated by Ion Modified Hexagonal Mesoporous Silica with Unexpected Enhanced Epoxidation Selectivity. Synthesis and Reactivity in Inorganic, Metal Organic, and Nano-Metal Chemistry, 46,

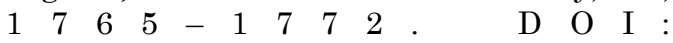
10.1080/15533174.2015.1137059. 
[115] Jiang, P., Chen, M., Dong, Y., Lu, Y., Ye, X., Zhang, W. (2009). Novel Two-Phase Catalysis with Organometallic Compounds for Epoxidation of Vegetable Oils by Hydrogen Peroxide. J. Am. Oil Chem. Soc., 87, 83-91. DOI: 10.1007/s11746-009-1469-1.

[116] Li, X., Jiang, P., Lu, Y., Zhang, W., Dong, Y. (2012). Synthesis of Hydrotalcite-like Com ounds Intercalated by 12 - Phosphorus Tungsten Heteropoly Acid and Catalytic Performance on the Epoxidation of Fatty Acid Methyl Esters. Acta Chim. Sin., 70, 544. DOI: 10.6023/A1108261.

[117] Sahoo, D.P., Nayak, S., Reddy, K.H., Martha, S., Parida, K. (2018). Fabrication of a $\mathrm{o}(\mathrm{OH})_{2} / \mathrm{ZnCr} \mathrm{LDH}$ "p-n" Heterojunction Photocatalyst with Enhanced Separation of Charge Carriers for Efficient Visible-Light Driven $\mathrm{H}_{2}$ and $\mathrm{O}_{2}$ Evolution. Inorg. Chem., 57 ( 7 ), $\quad 3840-3854$. D O I : 10.1021/acs.inorgchem.7b03213.

[118] Sahoo, M., Mansingh, S., Subudhi, S., Mohapatra, P., Parida, K.M. (2019). A plasmonic AuPd bimetallic nanoalloy decorated over a GO/LDH hybrid nanocomposite via a green synthesis route for robust Suzuki coupling reactions: a paradigm shift towards a sustainable future. Catalysis Science and Technology, 9, 4678- 4692. DOI: 10.1039/C9CY01085H.

[119] Sahoo, M., Singha, S., Parida, K.M. (2011). Amine functionalized layered double hydroxide: a reusable catalyst for aldol condensation. New J. Chem., 35, 2503-2509. DOI: 10.1039/C1NJ20492K.

[120] Kuljiraseth, J., Wangriya, A., Malones, J.M.C., Klysubun, W., Jitkarnka, S. (2018). Synthesis and Characterization of AMO LDHderived mixed oxides with various $\mathrm{Mg} / \mathrm{Al}$ ratios as acid-basic catalysts for Esterification of benzoic acid with 2-ethylhexanol. Applied $\mathrm{Ca}$ talysis B: Environmental, 243, 415-427. DOI: 10.1016/j.apcatb.2018.10.073.

[121] Walker, V., Mills, G.A. (2001). Urine 4- heptanone: a 8 -oxidation product of 2 - ethylhexanoic acid from plasticizers. Clin. Chim. Acta., 306, 51-61. DOI: 10.1016/s00098981(01)00390-4.

[122] Parida, K., Das, J. (2000). Mg/Al hydrotalcites: preparation, characterization and ketonisation of acetic acid. J. Molec. Catal. A Chem., 151, 185-192. DOI: 10.1016/S13811169(99)00240-X.

[123] Wang, Y., Yan, D., Hankari, S.E., Zou, Y., Wang, S. (2018). Recent progress on layered double hydroxides and their derivatives for electrocatalytic water splitting. Advanced Science, $\quad 5$ ( 8), $\quad 1800064$. D O : $10.1002 /$ advs. 201800064 .
[124] Suen, N.T., Hung, S.F., Quan, Q., Zhang, N., $\mathrm{Xu}$, Y.J., Chen, H.M. (2017). Electrocatalysis for the oxygen evolution reaction: recent development and future perspectives. Chemical Society Reviews, 46(2), 337-365. DOI: 10.1039/C6CS00328A.

[125] Wu, L., Yu, L., Xiao, X., Zhang, F., Song, S., Chen, S., Ren, Z. (2020). Review Article Recent Advances in Self-Supported Layered Double Hydroxides for Oxygen Evolution Reaction. AAAS Research, 2020, 3976278. DOI: 10.34133/2020/3976278.

[126] Trotochaud, L., Young, S.L., Ranney, J.K., Boettcher, S.W. (2014). Nickel-iron oxyhydroxide oxygen-evolution electrocatalysts: the role of intentional and incidental iron incorporation. J. Am. Chem. Soc., 136, 6744-6753. DOI: $10.1021 / \mathrm{ja} 502379 \mathrm{c}$.

[127] Lyu, F., Wang, Q., Choi, S.M., Yin, Y. (2019). Noble-metal-free electrocatalysts for oxygen evolution. Small (Weinheim an der Bergstrasse, Germany), 15(1), 1804201. DOI: 10.1002/smll.201804201.

[128] Vij, V., Sultan, S., Harzandi, A.M. Abhishek, M., Jitendra, N.T., Wang-Geum, L., Taeseung, Y., Kwang, S.K. (2017). Nickel-based electrocatalysts for energy-related applications: oxygen reduction, oxygen evolution, and hydrogen evolution reactions. ACS Catalysis, 7(10) , 7196-7225. DOI: 10.1021/acscatal.7b01800.

[129] Xiao, X., Huang, D., Fu, Y. Ming, W., Xingxing, J., Xiaowei, L., Lin, G., Shuangshuang, L., Mengkui, W., Chuan, Z., Yan, S. (2018). Engineering NiS/Ni2P heterostructures for efficient electrocatalytic water splitting. ACS Applied Materials \& Interfaces, $10(5), \quad 4689-4696$. D O I : 10.1021/acsami.7b16430.

[130] Mingfei, S., Ruikang, Z., Zhenhua, L., Min, W., David, G.E., Xue, D. (2015). Layered double hydroxides toward electrochemical energy storage and conversion: design, synthesis and applications. Chemical Communications, 51, 15880-15893. DOI: 10.1039/C5CC07296D.

[131] Jing, H., Xiaomin, T., Qing, D., Zhiqiang, L., Huamin, Z., Anmin, Z., Zhizhang, Y., Xianfeng, L. (2021). Layered double hydroxide membrane with high hydroxide conductivity and ion selectivity for energy storage device. Nature Communications, 12, 3409, 1-10. DOI: $10.1038 / \mathrm{s} 41467-021-23721-9$.

[132] Likius, D., Rahman, A., Zivayi, C., Uahengo, V. (2020). Recent Advances on the Use of Nickel Nano Layered Double Hydroxides as Green, and Efficient, Catalysts for Water Splitting. Catalysis Letters, 150, 1942-1956. DOI: 10.1007/s10562-019-03095-w. 
[133] Chen, C., Li, T., Shiqian, D., Wei, C., Yanyong, W., Yuqin, Z., Shuangyin, W. (2020). Advanced Exfoliation Strategies for Layered Double Hydroxides and Applications in Energy Conversion and Storage. Advanced Functional Materials. 30, 14, 1909832. DOI: 10.1002/adfm.201909832.

[134] Rong, L., Yanyong, W., Dongdong, L., Yuqin, Z., Shuangyin, W. (2017). Water-PlasmaEnabled Exfoliation of Ultrathin Layered Double Hydroxide Nanosheets with Multivacancies for Water Oxidation. Advanced Materials, 29, 30, 1701546 . DOI: 10.1002/adma.201701546.

[135] Uwasu, M., Hara, K., Yabar, H. (2014). World cement production and environmental implications. Environ. Dev., 10, 36-47. DOI: 10.1016/j.envdev.2014.02.005.

[136] Kim, Y., Worrell, E. (2002). CO2 emission trends in the cement industry: An international comparison. Mitig. Adapt. Strateg. Glob. Chang., 7, 115-133. DOI: 10.1023/A:1022857829028.

[137] Tuutti, K. (1982). Corrosion of Steel in Concrete, Technical Report, Cement-och Betonginst CBI Sweden, Stockholm, Sweden.

[138] Bertolini, L., Elsener, B., Pedeferri, P., Redaelli, E., Polder, R. (2013). Corrosion of Steel in Concrete Volume 392. Weinheim, Germany: Wiley-Vch.

[139] Cai, H., Liu, X. (1998). Freeze-thaw durability of concrete: Ice formation process in pores. Cem. Concr. Res., 28, 1281-1287. DOI: 10.1016/S0008-8846(98)00103-3.

[140] Huovinen, S. (1990). Abrasion of Concrete by Ice in Arctic Sea Structures, Technical, Research Centre of Finland, Espoo, Finland.

[141] Jacobsen, S., Scherer, G.W., Schulson, E.M. (2015). Concrete-ice abrasion mechanics. Cem. Concr. Res., 73, 79-95. DOI: 10.1016/j.cemconres.2015.01.001.

[142] Attiogbe, E.K., Rizkalla, S.H. (1988). Response of concrete to sulfuric acid attack. $A C I$ Mater. J., 85, 481-488.

[143] Yoon, S., Moon, J., Bae, S., Duan, X., Giannelis, E.P., Monteiro, P.M. (2014). Chloride adsorption by calcined layered double hydroxides in hardened Portland cement paste. $M a$ ter. Chem. Phys., 15, 376-386. DOI: 10.1016/j.matchemphys.2014.02.026.

[144] Mir, Z.M., Bastos, A., Höche, D., Zheludkevich, M.L. (2020). Recent Advances on the Application of Layered Double Hydroxides in Concrete. Materials, 13, 1426. DOI: 10.3390/ma13061426.
[145] Zahid, M.M, Alexandre, B., Daniel, H., Mikhail, L.Z. (2020). Recent Advances on the Application of Layered Double Hydroxides in Concrete A Review, Materials. 13, 1426; 1-23. DOI: $10.3390 / \mathrm{ma} 13061426$.

[146] José Ignacio, V., Mònica, A., Marcelo, A. (2012). Layered double hydroxides (LDHs) as functional fillers in polymer composites. Advances in Polymer Nanocomposites: Types and applications 91-130, 1st, Chapter: 4, Publisher: Woodhead Publishing, Editors: Fengge Gao. DOI: 10.1533/9780857096241.1.91.

[147] Du, L.C., Qu, B.J. (2007). Effects of synthesis conditions on crystal morphological structures and thermal degradation behavior of hydrotalcites and flame retardant and mechanical properties of EVA/hydrotalcite blends. Polym. Compos., 28, 131-138. DOI: 10.1002/pc.20279.

[148] Jiao, C.M., Wang, Z.Z., Ye, Z., Hu, Y., Fan, W.C. (2006). Flame retardation of ethylenevinyl acetate copolymer using nano magnesium hydroxide and nano hydrotalcite. J. Fire Sci., $24, \quad 47-6 \quad 4$. D O I : $10.1177 / 0734904106053160$.

[149] Costache, M.C., Heidecker, M.J., Manias, E., Camion, G., Frache, A., Beyer, G. (2007). The influence of carbon nanotubes, originally modified montmorillonites and layered double hydroxides on the thermal degradation and fire retardancy of polyethylene, ethylenevinyl acetate polystyrene. Polymer, 48, 65326545. DOI: 10.1016/j.polymer.2007.08.059.

[150] Prasad, C., Tang, H., Liu, W. (2018). Magnetic $\mathrm{Fe}_{3} \mathrm{O}_{4}$ based layered double hydroxides $(\mathrm{LDHs})$ nanocomposites $\left(\mathrm{Fe}_{3} \mathrm{O}_{4} / \mathrm{LDHs}\right)$ : recent review of progress in synthesis, properties and applications. Journal of Nanostructure in Chemistry, 8, 393-412. DOI: 10.1007/s40097018-0289-y.

[151] Daud, M., Kamal, M.S., Shehzad, F., AlHarthi, M.A. (2016). Graphene/layered double hydroxides nanocomposites: a review of recent progress in synthesis and applications. Carbon, 104, 241-252. DOI: 10.1016/j.carbon.2016.03.057.

[152] Nalawade, P., Aware, B., Kadam, V.J., Hirlekar, R.S. (2009). Layered Double Hydroxides: A Review. Journal of Scientific \& Industrial Research, 267(68), 267-272.

[153] Choy, J.H., Kwak, S.Y., Park, J.S., Jeong, Y.J. (2001). Cellular uptake behavior of [c32P] labeled ATP-LDH nanohybrids. $J$. Mater. Chem., 11, 1671-1674. DOI: 10.1039/B008680. 
[154] Umberto, C., Valeria, B., Giuliana, G., Francesca, M., Morena, N., Loredana, T., Vittoria, V. (2009). New Polymeric Composites Based on Poly(caprolactone) and Layered Double Hydroxides Containing Antimicrobial Species. Applied Materials and Interfaces, 1, 3, 668677. DOI: 10.1021/am8001988.

[155] Umberto, C., Morena, N., Michele, S., Riccardo, V. (2009). Recent progress in the synthesis and application of organically modified hydrotalcites. Z. Kristallogr., 224, 273-281. DOI: 10.1524/zkri.2009.1153.

[156] Mardani, H.R. (2017). (Cu/Ni)-Al layered double hydroxides@Fe3O4 as efficient magnetic nano composite photo catalyst for visible light degradation of methylene blue. Res. Chem. Intermed., 10, 5795-5810. DOI: 10.1007/s11164017-2963-y.

[157] Chunming, S (2017). Environmental implications and applications of engineered nanoscale magnetite and its hybrid nanocomposites: A review of recent literature. J. Hazard. Mater., $322(\mathrm{Pt} \quad \mathrm{A}):$ 48-84. DOI: 10.1016/j.jhazmat.2016.06.060.

[158] Lu, L., Li, J., Ng, D.H., Yang, P., Song, P., Zuo, M. (2017). Synthesis of novel hierarchically porous $\mathrm{Fe}_{3} \mathrm{O}_{4} @ \mathrm{MgAl}-\mathrm{LDH}$ magnetic microspheres and its superb adsorption properties of dye from water. J. Ind. Eng. Chem., 46, 315-323. DOI: 10.1016/j.jiec.2016.10.045.

[159] Parida, K., Satpathy, M., Mohapatra, L. (2012). Incorporation of $\mathrm{Fe}^{3+}$ into $\mathrm{Mg} / \mathrm{Al}$ layered double hydroxide framework effects on textural properties and photocatalytic activity for $\mathrm{H}_{2}$ generation. J. Mater. Chem., 22, 73507357. DOI: 10.1039/C2JM15658J.

[160] Ran-ran, S., Liang-guo, Y., Kun, Y., Yuanfeng, H., Bin, D. (2015). Adsorption of Cd(II) by $\mathrm{Mg}-\mathrm{Al}-\mathrm{CO} 3-$ and magnetic $\mathrm{Fe}_{3} \mathrm{O}_{4} / \mathrm{Mg}-\mathrm{Al}-$ CO3-layered double hydroxides: Kinetic, isothermal, thermodynamic and mechanistic studies. Journal of Hazardous Materials, 299, $\begin{array}{llllllll}4 & 2 & - & 4 & 9 & \text { D } & \text { O I : }\end{array}$ 10.1016/j.jhazmat.2015.06.003Get.

[161] Zhang, H., Zhang, G., Bi, X., Chen, X. (2013). Facile assembly of a hierarchical core@shell $\mathrm{Fe}_{3} \mathrm{O}_{4} @ \mathrm{CuMgAl}-\mathrm{LDH}$ (layered double hydroxide) magnetic nanocatalyst for the hydroxylation of phenol. J. Mater. Chem. A, 1, 59345942. DOI: 10.1039/C3TA10349H.

[162] Komarala, E.V.P., Nigam, S., Aslam, M., Bahadur, D. (2016). In-vitro evaluation of layered double hydroxide- $\mathrm{Fe}_{3} \mathrm{O}_{4}$ magnetic nanohybrids for thermo-chemotherapy. New J. Chem., 40, 4 23-433. DO : 10.1039/C5NJ01701G.
[163] Wang, R.X., Wen, T., Wu, X.L., Xu, A.W. (2014). Highly efficient removal of humic acid from aqueous solutions by $\mathrm{Mg} / \mathrm{Al}$ layered double hydroxides- $\mathrm{Fe}_{3} \mathrm{O}_{4}$ nanocomposites. $R S C$ Advances, 4, 21802-21809. DOI: 10.1039/C4RA02212B.

[164] Hu, W., Wu, X., Jiao, F., Yang, W., Zhou, Y. (2016). Preparation and characterization of magnetic $\mathrm{Fe}_{3} \mathrm{O}_{4} @$ sulfonated B-cyclodextrin intercalated layered double hydroxides for methylene blue removal. Desalination Water Treat., 57, $1-12$. D O I : 10.1080/19443994.2016.1155173.

[165] Zhang, X., Wang, J., Li, R., Dai, Q., Gao, R., Liu, Q., Zhang, M. (2013). Preparation of $\mathrm{Fe}_{3} \mathrm{O}_{4} @ \mathrm{C} @$ layered double hydroxide composite for magnetic separation of uranium. Ind. Eng. Chem. Res., 52, 10152-10159. DOI: 10.1021/ie3024438.

[166] Chen, D., Li, Y., Zhang, J., Zhou, J., Guo, Y., $\mathrm{Liu}, \mathrm{H}$. (2012). Magnetic $\mathrm{Fe}_{3} \mathrm{O}_{4} / \mathrm{ZnCr}$-layered double hydroxide composite with enhanced adsorption and photo catalytic activity. Chem. Eng. J., 185(186): 120-126. DOI: 10.1016/j.cej.2012.01.059.

[167] Wang, X., Zhou, S., Wu, L. (2014). Fabrication of $\mathrm{Fe}^{3+}$ doped $\mathrm{Mg} / \mathrm{Al}$ layered double hydroxides and their application in UV light shielding coatings. J. Mater. Chem. C., 2, 5752-5758. DOI: 10.1039/C4TC00437J.

[168] Yan, L., Yang, K., Shan, R., Yu, H., Du, B. (2015). Calcined $\mathrm{ZnAl}$ - and $\mathrm{Fe}_{3} \mathrm{O}_{4} / \mathrm{ZnAl}$ layered double hydroxides for efficient removal of $\mathrm{Cr}(\mathrm{VI})$ from aqueous solution. RSC $A d$ vances, 5, 96495-96503. DOI: 10.1039/C5RA17058C.

[169] Pan, D., Zhang, H., Fan, T., Chen, J., Duan, X. (2011). Nearly monodispersed core-shell structural $\mathrm{Fe}_{3} \mathrm{O}_{4} @$ DFUR-LDH sub micro particles for magnetically controlled drug delivery and release. Chem. Commun., 47, 908910. DOI: 10.1039/C0CC01313G.

[170] Ni, J., Xue, J., Xie, L., Shen, J., He, G., Chen, H. (2018). Construction of magnetically separable $\mathrm{NiAl} \mathrm{LDH} / \mathrm{Fe}_{3} \mathrm{O}_{4}-\mathrm{RGO}$ nanocomposites with enhanced photocatalytic performance under visible light. Phys. Chem. Chem. Phys., 20, 414-421. DOI: 10.1039/C7CP06682A.

[171] Koilraj, P., Sasaki, K. (20160. $\mathrm{Fe}_{3} \mathrm{O}_{4} / \mathrm{MgAlNO}_{3}$ layered double hydroxide as a magnetically separable sorbent for the remediation of aqueous phosphate. J. Environ. Chem. Eng., 4, 984-991. DOI: 10.1016/j.jece.2016/01.005.

[172] Moaser, A.G., Khoshnavazi, R. (2017). Facile synthesis and characterization of $\mathrm{Fe}_{3} \mathrm{O}_{4} @ \mathrm{MgAl}-\mathrm{LDH} @ S T P O M$ nanocomposite with highly enhanced and selective degradation of methylene blue. New J. Chem., 41, 9472-9481. DOI: 10.1039/C7NJ00792B. 
[173] Mi, F., Chen, X., Ma, Y., Yin, S., Yuan, F., Zhang, H. (2011). Facile synthesis of hierarchical core-shell $\mathrm{Fe}_{3} \mathrm{O}_{4} @ \mathrm{MgAl}-\mathrm{LDH} @ \mathrm{Au}$ as magnetically recyclable catalysts for catalytic oxidation of alcohols. Chem. Commun., 47, 12804-12806. DOI: 10.1039/c1cc15858a.

[174] Chen, D., Li, Y., Zhang, J., Li, W., Zhou, J., Shao, L., Qian, G. (2012). Efficient removal of dyes by a novel magnetic $\mathrm{Fe}_{3} \mathrm{O}_{4} / \mathrm{ZnCr}$-layered double hydroxide adsorbent from heavy metal wastewater. J. Hazard. Mater., 243, 152-160. DOI: 10.1016/j.jhazmat.2012.10.014.

[175] Shan, R., Yan, L., Yang, K., Yu, S., Hao, Y., $\mathrm{Yu}, \quad$ H., Du, B. (2014). Magnetic $\mathrm{Fe}_{3} \mathrm{O}_{4} / \mathrm{MgAlLDH}$ composite for effective removal of three red dyes from aqueous solution. Chem. Eng. J., 15, 38-46. DOI: 10.1016/j.cej.2014.04.105.

[176] Chen, X., Mi, F., Zhang, H., Zhang, H. (2012). Facile synthesis of a novel magnetic coreshell hierarchical composite submicrospheres $\mathrm{Fe}_{3} \mathrm{O}_{4} @ \mathrm{CuNiAl}-\mathrm{LDH}$ under ambient conditions. Mater. Lett., 69, 48-51. DOI: 10.1016/j.matlet.2011.11.052.

[177] Wu, X.L., Wang, L., Chen, C.L., Xu, A.W., Wang, X.K. (2011). Waterdispersible magnetite-graphene-LDH composites for efficient arsenate removal. J. Mater. Chem., 21, 1735317359. DOI: 10.1039/C1JM12678D.

[178] Zhao, X., Wang, W.Y., Li, X.D., Li, S., Song, F. (2018). Core-shell structure of $\mathrm{Fe}_{3} \mathrm{O}_{4} @ \mathrm{MTXLDH} / \mathrm{Au}$ NPs for cancer therapy. Mater. Sci. Eng. C, 89, 422-428. DOI: 10.1016/j.msec.2018.04.024.

[179] Shao, M., Ning, F., Zhao, J., Wei, M., Evans, D.G., Duan, X. (2012). Preparation of $\mathrm{Fe}_{3} \mathrm{O}_{4} @ \mathrm{SiO}_{2} @$ layered double hydroxide coreshell microspheres for magnetic separation of proteins. J. Am. Chem. Soc., 134, 1071-1077. DOI: $10.1021 /$ ja2086323.

[180] Magdalena, W., Małgorzata, K.K., Alina, P., Grzegorz, R., Tomasz, B. (2019). Removal of Heavy Metals and Metalloids from Water Using Drinking Water Treatment Residuals as Adsorbents: A Review. Minerals, 9, 487, 1-17. DOI: $10.3390 / \min 9080487$.

[181] Marcella, B., Francesco, M. (2018). Layered double hydroxides $(\mathrm{LDHs})$ : versatile and powerful hosts for different applications. Journal of Analytical \& Pharmaceutical Research, 7, 1, 14-12. DOI: 10.15406/japlr.2018.07.00206.

[182] Lekbira, E.M., Mountassir, E.M., El-Mostafa, M., Claude, F., Mohammadine, E.H., Samir, B., Abdelaaziz, A.T., Salah, R. (2021). ZnCrLDHs with dual adsorption and photocatalysis capability for the removal of acid orange 7 dye in aqueous solution. Journal of Science: Advanced Materials and Devices, 6, 1, 118126. DOI: $10.1016 /$ j.jsamd.2020.08.002.
[183] Dang, M., Hue, T.M., Trinh, D.V., Nguyen, N.K., Nguyen, T., Dung, D., Tran, D., Hoang, V., Phan, H., Huynh, C.D. (2018). Enhanced Photocatalytic Activity for Degradation of Organic Dyes Using Magnetite $\mathrm{CoFe}_{2} \mathrm{O}_{4} / \mathrm{BaTiO}_{3}$ Composite. Journal of Nanoscience and Nanotechnology, 18, 11, 7850-7857. DOI: 10.1166/jnn.2018.15542.

[184] Osama, S., Hicham, M.K. (2020). Designing Dual-Function Nanostructures for Water $\mathrm{Pu}$ rification in Sunlight. Appl. Sci., 10, 1786; 119. DOI: $10.3390 /$ app10051786.

[185] Starukh, H., Levytska, S. (2019). The simultaneous anionic and cationic dyes removal with $\mathrm{Zn} \mathrm{Al} \mathrm{layered} \mathrm{double} \mathrm{hydroxides.} \mathrm{Ap-}$ plied Clay Science, 180(8), 105183. DOI: 10.1016/j.clay.2019.105183.

[186] Pshinko, G.N. (2013). Layered Double Hydroxides as Effective Adsorbents for U(VI) and Toxic Heavy Metals Removal from Aqueous Media. Journal of Chemistry, 347178, 19. DOI: $10.1155 / 2013 / 347178$.

[187] Linghu, W.; Yang, H.; Sun, Y.; Sheng, G.; Huan, Y (2017). One-pot synthesis of LDH/GO composites as high effective adsorbent for the decontamination of U(VI). ACS Sustain. Chem. Eng., 5, 5608-5616. DOI: 10.1021/acssuschemeng.7b01303.

[188] Saber, O.; Aljaafari, A.; Osama, M.; Alabdulgader, H (2018). Accelerating the Photocatalytic Degradation of Green Dye Pollutants by Using a New Coating Technique for Carbon Nanotubes with Nanolayered Structures and Nanocomposites. Chemistry Open, 7, 833841. DOI: 10.1002/open.201800173.

[189] Reena, S., Neetu, G., Anurag, M., Rajiv, G. (2011). Heavy metals and living systems: An overview. Indian J. Pharmacol., 43(3), 246253. DOI: 10.4103/0253-7613.81505.

[190] Muhammad, S., Bertrand, P., Camille, D., Muhammad, N., Muhammad, A., Eric, P. (2014). Heavy-metal-induced reactive oxygen species: phytotoxicity and physicochemical changes in plants. Rev. Environ. Contam. Toxicol. 14, 232, 1-44. DOI: 10.1007/978-3319-06746-9_1.

[191] Kano, N., Zhang, S. (2018). Adsorption of Heavy Metals on Layered Double Hydroxides (LDHs) Intercalated with Chelating Agents. Intech Open. DOI: 10.5772/intechopen.80865.

[192] Perez, M.R., Pavlovic, I., Barriga, C., Cornejo, J., Hermosin, M.C., Ulibarri, M.A. (2006). Uptake of $\mathrm{Cu}^{2+}, \mathrm{Cd}^{2+}$ and $\mathrm{Pb}^{2+}$ on $\mathrm{Zn}-\mathrm{Al}$ layered double hydroxide intercalated with EDTA. Applied Clay Science, 32(3), 245-251. DOI: 10.1016/j.clay.2006.01.008. 
[193] Gasser, M.S., Aly, H.F. (2009). Kinetic and adsorption mechanism of $\mathrm{Cu}(\mathrm{II})$ and $\mathrm{Pb}(\mathrm{II})$ on prepared nanoparticle layered double hydroxide intercalated with EDTA. Colloids and Surfaces A: Physicochemical and Engineering Aspects, 6(1-3), 167-173. DOI: 10.1016/j.colsurfa.2008.11.047.

[194] Zahir, M.H., Irshad, K., Rahman, M.M., Shaikh, M.N., Rahman, M.M. (2021). Efficient Capture of Heavy Metal Ions and Arsenic with a CaY-Carbonate Layered DoubleHydroxide Nanosheet. ACS Omega, 6(35),

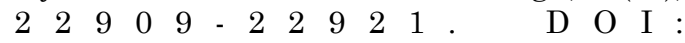
10.1021/acsomega.1c03294.

[195] Buxbaum, G., Pfaff, G. (2005). Cadmium Pigments, Industrial Inorganic Pigments. Hoboken, New Jersey, USA: Wiley-VCH.

[196] Shan, R., Yan, L., Yang, K., Hao, Y., Du, B. (2015). Adsorption of $\mathrm{Cd}(\mathrm{II})$ by $\mathrm{Mg}-\mathrm{Al}-\mathrm{CO} 3$ and magnetic $\mathrm{Fe}_{3} \mathrm{O}_{4} / \mathrm{Mg}-\mathrm{Al}-\mathrm{CO} 3$-layered double hydroxides: kinetic, isothermal, thermo dynamic and mechanistic studies. Hazard. Mater., $299, \quad 42-49$. D O : 10.1016/j.jhazmat.2015.06.003.

[197] Zhang, F., Song, Y., Song, S., Zhang, R., Hou, W. (2015). Synthesis of magnetite-graphene oxide-layered double hydroxide composites and applications for the removal of $\mathrm{Pb}$ (II) and 2, 4-dichlorophenoxyacetic acid from aqueous solutions. ACS Appl. Mater. Interfaces, 7, 7251-7263. DOI: 10.1021/acsami.5b00433.

[198] Lijiao, M., Qing, W., Saiful, M.I, Yingchun, L., Shulan, M., Mercouri, G.K. (2016). Highly Selective and Efficient Removal of Heavy Metals by Layered Double Hydroxide Intercalated with the $\mathrm{MoS}_{4}{ }^{(2-)}$ Ion. J. Am. Chem. Soc. 138(8), 2858-2866. DOI: 10.1021/jacs.6b00110.
[199] Jawad, A., Liao, Z., Zhou, Z., Khan, A., Wang, T., Ifthikar, J., Shahzad, A., Chen, Z., Chen, Z. (2017). Fe-MoS 4 : An Effective and Stable LDH-Based Adsorbent for Selective Removal of Heavy Metals. ACS Appl. Mater. Interfaces. $30, \quad 9(34), \quad 28451-28463$. doi: 10.1021/acsami.7b07208.

[200] Asiabi, H., Yamini, Y., Shamsayei, M., Molaei, K., Shamsipur, M. (2018). Functionalized layered double hydroxide with nitrogen and sulfur co-decorated carbon dots for highly selective and efficient removal of soft $\mathrm{Hg}^{2+}$ and $\mathrm{Ag}^{+}$ions. J. Hazard. Mater. 357, 217-225. DOI: 10.1016/j.jhazmat.2018.05.055.

[201] Yang, L., Xie, L., Chu, M., Wang, H., Yuan, M., Yu, Z., Wang, C., Yao, H., Islam, S.M., Shi, K., Yan, D., Ma, S., Kanatzidis, M.G. (2022) $\mathrm{Mo}_{3} \mathrm{~S}_{132}$-Intercalated Layered Double Hydroxide: Highly Selective Removal of Heavy Metals and Simultaneous Reduction of $\mathrm{Ag}^{+}$Ions to Metallic Ag0 Ribbons. Angew. Chem. Int. Ed. Engl., 61(1), e202112511. DOI: 10.1002/anie.202112511.

[202] Ekubatsion, L.H., Thriveni, T., Ahn, J.W. (2021). Removal of $\mathrm{Cd}^{2+}$ and $\mathrm{Pb}^{2+}$ from Wastewater through Sequent Addition of KRSlag, $\mathrm{Ca}(\mathrm{OH})_{2}$ Derived from Eggshells and $\mathrm{CO}_{2}$ Gas. ACS Omega, 6(42), 27600-27609. DOI: 10.1021 /acsomega.1c00946.

[203] Liang, X., Hou, W., Xu, Y., Sun, G., Wang, L., Sun, Y., Qin, X. (2010). Sorption of lead ion by layered double hydroxide intercalated with diethylenetriaminepentaacetic acid. Colloids and Surfaces A: Physicochemical and Engineering Aspects. 366(1), 50-57. DOI: 10.1016/j.colsurfa.2010.05.012. 